
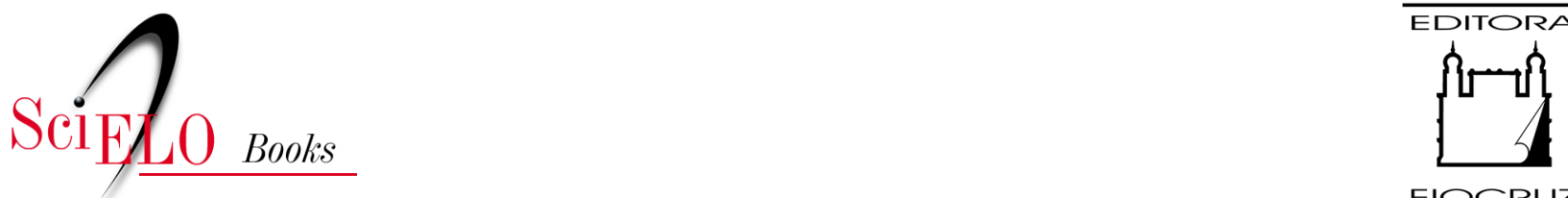

FIOCRUZ

\title{
Vigilância das doenças imunopreveníveis
}

\author{
Gloria Regina da Silva e Sá \\ Regina Fernandes Flauzino
}

\section{SciELO Books / SciELO Livros / SciELO Libros}

SÁ, G.R.S., and FLAUZINO, R.F. Vigilância das doenças imunopreveníveis. In: SILVA, M.N., FLAUZINO, R.F., GONDIM, G.M.M., eds. Rede de frio: fundamentos para a compreensão do trabalho [online]. Rio de Janeiro: Editora FIOCRUZ, 2017, pp. 179-214. ISBN: 978-65-5708-0917. https://doi.org/10.7476/9786557080917.0009.

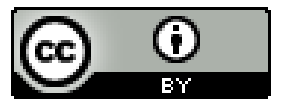

All the contents of this work, except where otherwise noted, is licensed under a Creative Commons Attribution 4.0 International license.

Todo o conteúdo deste trabalho, exceto quando houver ressalva, é publicado sob a licença Creative Commons Atribição 4.0.

Todo el contenido de esta obra, excepto donde se indique lo contrario, está bajo licencia de la licencia Creative Commons Reconocimento 4.0. 


\section{Vigilância das doenças imunopreveníveis}

Gloria Regina da Silva e Sá e Regina Fernandes Flauzino

Algumas das maiores conquistas da epidemiologia foram obtidas na prevenção e no controle das doenças transmissíveis. Sabe-se que uma doença infecciosa transmissível é uma enfermidade causada pela transmissão de um agente infeccioso específico, ou de seus produtos tóxicos, de uma pessoa ou animal infectados a um hospedeiro suscetível. Portanto, a diferença entre doenças transmissíveis e as não transmissíveis é a capacidade de contágio, ou seja, transmissão de um agente causador (microrganismo) de pessoa a pessoa, de uma animal ou inseto à pessoa, ou a partir de uma fonte comum.

Dentre as doenças transmissíveis, um grupo é passível de ser evitado se utilizarmos, como estratégia, a vacinação da população. O conhecimento sobre as doenças imunopreveníveis, suas principais medidas preventivas e de controle, individuais e coletivas, é essencial para os profissionais da rede de frio de imunobiológicos; aliás, é parte integrante do seu objeto de trabalho, porque, a partir desse conhecimento, é possível compreender a função do imunobiológico no controle de doenças, bem como as ações de vigilância epidemiológica.

Neste capítulo, vamos apresentar as principais doenças imunopreveníveis, suas definições, sinais e sintomas, formas de transmissão, complicações e a vigilância e o impacto epidemiológicos relacionados a elas.

\section{Iniciando uma conversa sobre as doenças imunopreveníveis}

Para melhor compreensão do comportamento e da evolução das doenças infecciosas, os estudos e as discussões não devem apenas verificar 
sua distribuição no tempo, espaço e segundo os atributos da população, mas, sobretudo, fundamentá-los em consonância com seus determinantes em nível dos sistemas biológico, econômico e político, compreendidos como um todo inter-relacionado e interdependente.

[...] a compreensão do processo infeccioso se dá pela observação contínua dos diversos fenômenos que ocorrem de forma interdependente e inter-relacionada no âmbito dos sistemas e subsistemas envolvidos. Com fundamento nesse referencial teórico, $[\ldots]$ pode-se entender melhor fenômenos como o recrudescimento da malária na Amazônia a partir dos anos 70, o aparecimento de novas doenças como a febre purpúrica brasileira e mesmo a introdução e disseminação da AIDS no país (WALDMAN; SILVA; MONTEIRO, 1999, p. 43).

Nessa perspectiva, se reconhece a importância do controle das doenças transmissíveis no mundo, em função das muitas pandemias (por exemplo, cólera) e epidemias (por exemplo, peste, varíola) que assolaram continentes e que foram controladas por meio de estratégias de vigilância e de vacinação. As doenças imunopreveníveis são como um "termômetro" capaz de avaliar as ações de atenção básica, pois indicam onde essas doenças ocorrem, a existência de indivíduos ou grupos de suscetíveis e se houve falha no monitoramento da cobertura vacinal.

A análise desses fatores permitirá, ao longo do tempo e do espaço, avaliar a tendência da doença imunoprevenível, adequando as ações de prevenção e controle propostas. Essas medidas tornam as doenças transmissíveis passíveis de controle, eliminação e erradicação, e algumas delas são apresentadas a seguir.

Definições importantes sobre epidemiologia e estratégias de controle das doenças transmissíveis

Controle - uma doença transmissível está sob controle quando o número de casos ocorre com uma frequência tão baixa que deixa de ser um problema de magnitude para a saúde pública (por exemplo, difteria).

Eliminação - considera-se uma doença eliminada quando o número de casos é raro porque, em virtude das ações de vigilância epidemiológica e imunização, sua transmissão praticamente foi interrompida. No entanto, ainda requer que sejam mantidas ações de vigilância sob os casos suspeitos notificados (por exemplo, sarampo e rubéola).

Erradicação - quando uma doença deixa de ocorrer por extinção do seu agente causador, não havendo, portanto, como transmiti-la. Nesse caso, as medidas de vigilância podem ser mantidas, mas a vacinação torna-se desnecessária (por exemplo, varíola). 
Além dessas definições, há um conjunto de conceitos básicos de epidemiologia que apresentamos no Anexo A. Caso sinta dificuldades com alguns termos utilizados ao longo deste capítulo, consulte esse material indicado!

Os imunobiológicos que são utilizados no controle dessas doenças fazem parte de um programa. O Programa Nacional de Imunizações encontra-se inserido no âmbito da vigilância epidemiológica, a qual reúne dados de diversas fontes, os processa e desencadeia as ações relacionadas aos casos de determinadas doenças transmissíveis.

É fundamental que qualquer caso suspeito ou confirmado de doença transmissível prevenível por imunização seja notificado aos serviços de vigilância epidemiológica, o mais brevemente possível. Já vimos, no capítulo anterior, um exemplo prático relacionado à suspeita de sarampo em um paciente.

Ainda que o número de casos de algumas doenças imunopreveníveis tenha reduzido drasticamente, o seguimento do calendário vacinal se faz necessário para manter tais doenças eliminadas ou controladas, de tal modo que não caracterizem transtorno para a saúde pública.

\section{Doenças imunopreveníveis e as ações de vigilância}

Cada doença transmissível irá demandar ações de vigilância de acordo com suas especificidades. Essas ações vão desde medidas relacionadas a riscos e vulnerabilidades existentes no território (determinantes sociais), que podem potencializar a probabilidade de ocorrência do evento em pessoas e grupos, até medidas profiláticas, busca ativa, notificação e investigação de casos.

A seguir, serão apresentadas as principais medidas de vigilância epidemiológica relacionadas às doenças imunopreveníveis conforme o Programa Nacional de Vacinação.

\section{Hepatites virais}

As hepatites virais são causadas pelos vírus da hepatite A, B, C, D e E. No entanto, apenas as hepatites A e B são imunopreveníveis, por isso iremos nos ater a elas neste texto. 
No Brasil, estima-se que $2 \%$ a $7 \%$ da população seja portadora crônica do vírus da hepatite B.

Soroconversão é entendida como uma resposta da vacina, após a imunização, confirmada pelo alto nível de anticorpos no sangue do indivíduo.
São doenças cuja prevalência varia bastante, chegando a ser endêmicas em algumas regiões do país. Daí a necessidade de se desenvolver ações antecipatórias de proteção (promoção e prevenção) nos múltiplos espaços onde a população se encontra (na habitação, no trabalho, no lazer), de modo a evitar e diminuir a ocorrência de casos dessas doenças.

A hepatite B atinge indiscriminadamente vários grupos, por suas formas de transmissão - predominantemente sexual, também parenteral, vertical, por compartilhamento de objetos contaminados, em acidentes com exposição a material biológico, procedimentos cirúrgicos, entre outros. É mais acometida a parcela de adolescentes e adultos jovens. A evolução da hepatite B varia de manifestações agudas a cronicidade, sem cura, podendo causar cirrose e carcinoma hepático, e até mesmo levar à morte.

A imunização contra a hepatite $\mathrm{B}$ deve ser feita nas primeiras 12 horas de vida do bebê, na gestante, e em qualquer indivíduo até 49 anos de idade, indiscriminadamente. É a principal medida de prevenção no conjunto de ações de vigilância das hepatites virais, dentro de uma série de medidas que visa impedir a transmissão ou reduzir os danos decorrentes da infecção entre usuários de drogas injetáveis, por exemplo.

Além desta, é preciso atenção especial aos profissionais de saúde que trabalhem sob alto risco de transmissão da doença, mesmo com uso de equipamento de proteção individual. São solicitados exames para confirmar a soroconversão após a vacinação contra hepatite B. Pacientes submetidos a hemodiálise e transplantes também são monitorados regularmente quanto a essa e outras infecções.

Para ser acometido pela hepatite D, é necessário ser infectado pelo vírus da hepatite B. Assim, a prevenção de uma leva à prevenção da outra.

Já a hepatite A é uma doença transmitida através de água e alimentos contaminados por fezes dos portadores. É mais frequente onde as condições de saneamento são ruins, ou as boas práticas de manipulação de alimentos não são executadas conforme o preconizado. É doença imunoprevenível, e sua a vacina encontra-se disponível nas unidades de saúde.

A hepatite A é menos virulenta, e muitos indivíduos, ao se infectarem, permanecem assintomáticos. Porém, não são incomuns surtos de hepatite A em locais de aglomeração, como creches, acampamentos, canteiros de obras, quartéis e outros locais onde a fonte de infecção seja comum. 


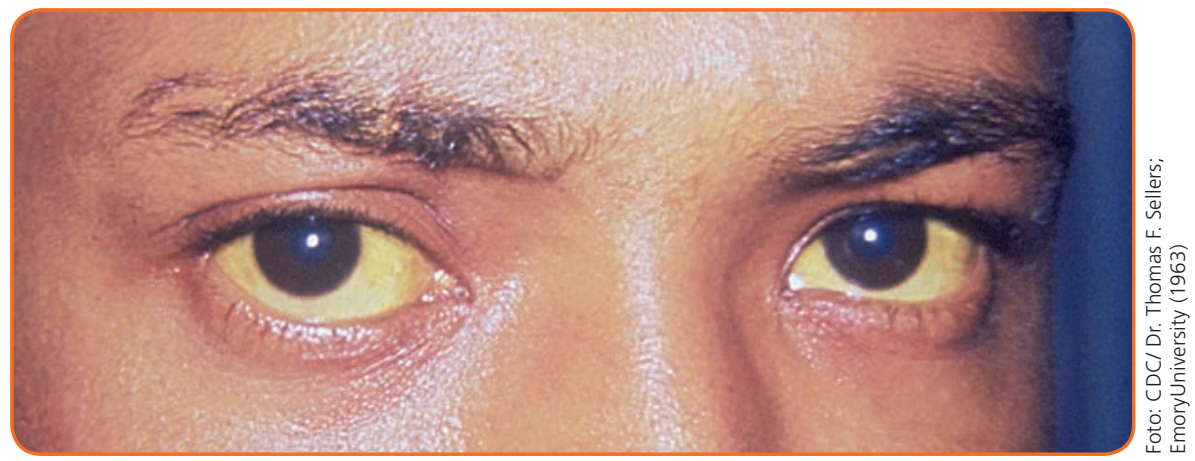

Um dos sintomas da hepatite A é o amarelamento dos olhos e da pele (icterícia), decorrente do mau funcionamento do fígado causado pelo vírus.

Os profissionais de saúde estão sob constante risco de exposição a hepatites virais e, em especial, hepatites B e C, que são transmitidas por via sanguínea e por objetos contaminados com sangue.

\section{Tuberculose}

Trata-se de doença respiratória causada pelo Mycobacterium tuberculosis (bacilo de Koch-BK), transmitida pessoa a pessoa. A evolução para casos graves, em geral, é incomum, e ela pode ser tratada em ambulatório, com algumas recomendações adicionais necessárias. No entanto, sua letalidade apresenta-se elevada entre indivíduos imunodeprimidos, especialmente se houver infecção concomitante com o vírus da imunodeficiência humana (HIV), porque esses pacientes já apresentam baixa imunidade, que favorece a evolução da doença.

A tuberculose tem forte associação com as condições de vida da população, como, por exemplo, as da habitação (iluminação, ventilação e quantidade de pessoas), de alimentação (quantidade e qualidade) e de acesso a serviços de saúde. Muitas pessoas e grupos vivem em condições de grande vulnerabilidade social em locais insalubres e sem infraestrutura adequada, cujas formas de viver, além de influenciar na imunidade, lhes atribui maior suscetibilidade para adoecer, quando da exposição ao bacilo.

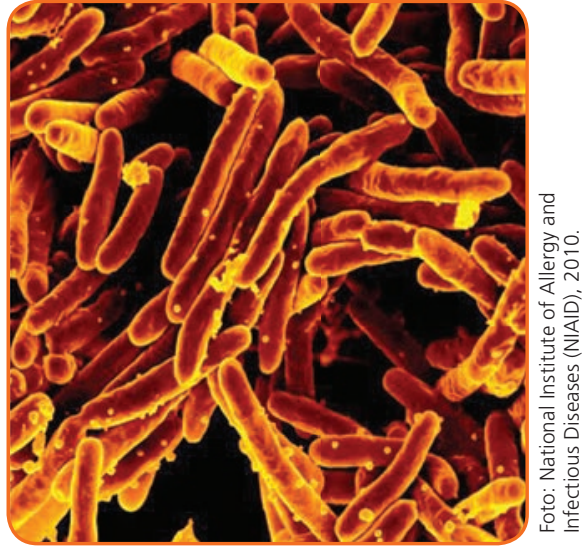

Bacilo de Koch, causador da tuberculose, visto por microscopia eletrônica colorida digitalmente.

Fonte: Public Health Images Library, Center of Disease Control. 
Mycobacterium tuberculosis (MTB), ou bacilo de Koch, é uma bactéria causadora dos casos de tuberculose (TB), descoberta pela primeira vez em 1882, por Robert Koch (FUNDAÇÃO NACIONAL DE SAÚDE, 2001).

Bacillus Calmette-Guérin (BCG) ou vacina contra a tuberculose é uma vacina obtida através da bactéria Mycobacterium bovis. A vacina, descoberta em 1925, leva esse nome em homenagem aos seus descobridores Albert León Charles Calmette e Jean Marie Camille Guérin (http://library.vetmed.fuberlin.de/vetbiogramm/57.html)

Meningite é uma doença caracterizada por um processo inflamatório das meninges, que são membranas que envolvem o cérebro (BRASIL, 2009).

Tuberculose miliar é um tipo de tuberculose com risco potencial à vida que ocorre quando um grande número de bactérias se desloca pela corrente sanguínea e se dissemina pelo corpo.
Secreções da nasofaringe são aquelas oriundas da região posterior a cavidade nasal (BRASIL, 2009).

A vacina contra tuberculose é a BCG (sigla para bacilo de Calmette-Guérin), que pode ser administrada imediatamente após o nascimento, desde que o bebê tenha mais de dois quilos.

Apesar de a tuberculose pulmonar ser um problema de grande magnitude, o que se pretende prevenir, na verdade, ao vacinar com a BCG, são as formas graves da doença, as extrapulmonares (fora dos pulmões), principalmente a meningite tuberculosa e a tuberculose miliar.

A vigilância epidemiológica da tuberculose abarca ações de prevenção (vacinação) e controle dos contatos intradomiciliares e íntimos do paciente e tratamento deste, com acompanhamento regular, pois não são raros os casos de abandono, sendo apontadas causas como intolerância aos medicamentos, abuso de álcool etc. O doente precisa receber apoio da equipe de saúde para que siga o tratamento até obter a cura e possa enfrentar a doença com todo o suporte necessário.

Sua prevalência é maior em áreas de grande concentração populacional e de precárias condições socioeconômicas e sanitárias. É uma doença com profundas raízes sociais, relacionada à má distribuição de renda e à pobreza; suas taxas variam de acordo com as regiões e, inclusive, dentro das mesmas regiões. Má alimentação, falta de higiene, tabagismo, alcoolismo ou qualquer outro fator que gere baixa resistência orgânica também favorece o estabelecimento da tuberculose (BRASIL, 2009).

\section{Difteria}

Ocorre durante todo o ano, havendo um aumento de incidência nos meses mais frios em função da sua forma de transmissão. Também conhecida como crupe, tem como agente causador a bactéria Corynebacterium diphteriae. A transmissão ocorre por contato direto com doentes ou portadores da bactéria, por meio de secreções da nasofaringe. A manifestação clínica mais frequente é a presença da pseudomembrana branco-acinzentada que pode surgir nas amígdalas e invadir as estruturas vizinhas, como mucosa ocular, traqueia e, em casos mais raros, vagina e pele.

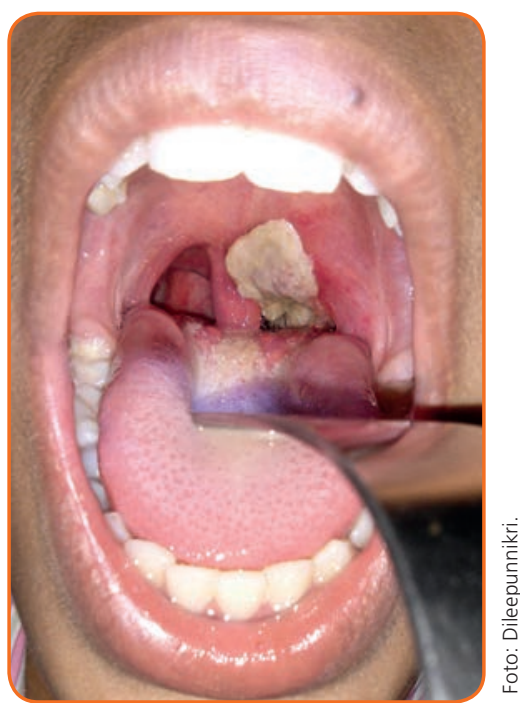

Pseudomembrana branco-acinzentada tipicamente observada em quadros de difteria.

Fonte: Wikimedia Commons 
O ideal é que todo caso suspeito tenha confirmação laboratorial através de cultura. O tratamento do doente consiste na aplicação de soro antidiftérico e antibioticoterapia.

A vigilância epidemiológica da difteria engloba ações de prevenção e controle dos contatos intradomiciliares (vacinação dos contatos suscetíveis) e íntimos do paciente e tratamento deste, com acompanhamento regular. A vigilância deve proceder a uma investigação cuidadosa, para captar outros possíveis casos e determinar a fonte de infecção.

Observa-se um aumento de sua incidência nos meses frios (outono e inverno), quando é mais comum a ocorrência de infecções respiratórias devidas, principalmente à aglomeração em ambientes fechados, que facilitam a transmissão do bacilo. É uma doença infecciosa de importância nos países do Terceiro Mundo; ocorre mais frequentemente em áreas com baixas condições socioeconômicas e sanitárias, onde a aglomeração de pessoas é maior. Comumente, essas áreas apresentam baixa cobertura vacinal, e, portanto, não é obtido impacto no controle da transmissão da doença (BRASIL, 2009).

\section{Coqueluche}

É uma doença infecciosa aguda, de alta transmissibilidade, caracterizada pela presença de tosse paroxística. É uma importante causa de morbimortalidade infantil, principalmente em lactentes, pelo grande número de complicações. Pode ocorrer sob a forma de epidemia ou endemia.

A transmissão ocorre através de gotículas de secreção da orofaringe, eliminadas por tosse, espirro ou no ato de falar de uma pessoa doente para uma pessoa suscetível e, menos frequentemente, por objetos contaminados pela secreção do doente (BRASIL, 2009).

As complicações mais comuns da coqueluche são pneumonia, enfisema pulmonar, otite média e apneia, entre outras, incluindo as complicações neurológicas (encefalopatia aguda, convulsões, coma, hemorragias cranianas, estrabismo e surdez).

Em indivíduos não adequadamente vacinados ou vacinados há mais de cinco anos, a coqueluche, frequentemente, não se apresenta sob a forma clássica, podendo manifestar-se sob formas atípicas, com tosse persistente, porém sem paroxismos, guincho característico ou vômito pós-tosse.
Tosse paroxística é aquela tosse súbita, incontrolável, com tossidas rápidas e curtas (5 a 10) em uma única expiração. 
Trismo refere-se à dificuldade de abrir a boca.

Espasmos são contrações involuntárias de um músculo ou grupo de músculos.

Opistótono é uma grande contratura formando curvatura em "ponte" dos pés à cabeça.
A vigilância epidemiológica da coqueluche engloba ações de prevenção e controle dos contatos intradomiciliares e íntimos do paciente (realização de vacinação de bloqueio, pesquisa de cultura de naso e orofaringe), procedendo a uma investigação cuidadosa, para captar outros possíveis casos.

Desde a década de 1990, tem-se observado uma redução significativa dos números de casos da doença. Avalia-se que isso seja devido às altas coberturas vacinais obtidas das vacinas tetravalente e tríplices bacteriana.

A coqueluche é uma doença de notificação compulsória, em todo o território nacional, e sua investigação laboratorial é obrigatória nos surtos e nos casos atendidos nas unidades sentinelas previamente determinadas, a fim de identificar a circulação da Bordetella pertussis.

\section{Tétano}

É uma doença infecciosa aguda, não contagiosa, relativamente comum em países subdesenvolvidos, nos quais a cobertura vacinal é baixa. É causado pela bactéria Clostridium tetani, potencialmente presente em toda a superfície terrestre. A transmissão ocorre pela introdução do agente em um ferimento, sobretudo através de material do tipo perfurocortante, ou em queimaduras e ferimentos necrosados.

Casos de tétano são caracterizados por dificuldade para engolir, trismo, contrações musculares localizadas ou generalizadas progressivas, com ou sem espasmos, opistótono, independentemente de história vacinal e doença prévia de tétano. A confirmação se dá pelo quadro clínico; o tratamento é feito com a administração de soro antitetânico e antibióticos.

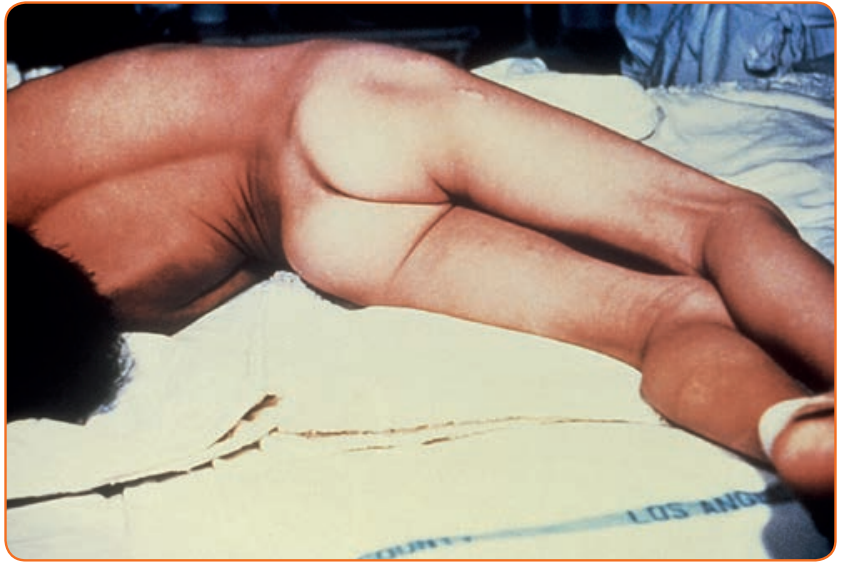

Paciente com tétano, apresentando postura conhecida como opistótono.

Fonte: Public Health Images Library, Center of Disease Control.
Ter sido acometido pela doença não confere imunidade, e a vacinação é a principal forma de prevenção do tétano. É importante vacinar a população desde a infância com a vacina antitetânica, composta por toxoide tetânico, associado a outros antígenos. O toxoide tetânico está presente nas vacinas tetra bacteriana, na tríplice bacteriana, na dupla dos tipos adulto e infantil, na pentavalente, podendo também ser oferecido apenas o tóxico tetânico. É necessária a administração de três doses, no mínimo, para a proteção adequada da doença.

A profilaxia vacinal do tétano é indicada, universalmente, para trabalhadores com risco ocupa- 
cional, idosos, gestantes, indivíduos que sofreram qualquer tipo de acidente, inclusive aqueles com animais peçonhentos. A vacina é oferecida, também, durante a profilaxia da raiva humana, por causa dos hábitos dos animais de viverem em solo, tocas, pedras, grutas, possivelmente, contaminadas com o bacilo do tétano.

A maioria dos casos de tétano acidental ocorre nas categorias dos aposentados-pensionistas, de trabalhadores agropecuários, seguidas pelos grupos de trabalhadores da construção civil (pedreiro) e donas de casa. Profissionais da saúde, militares, policiais, bombeiros, profissionais da aviação, profissionais que viajam muito, coletores de lixo, dejetos e águas contaminadas, alimentos e bebidas, profissionais que trabalham com crianças ou animais, manicures e podólogos constituem grupos para os quais a vacina está especialmente indicada.

No Brasil, observa-se um declínio do número de casos de tétano acidental. Na década de 1990, foram registrados mais de mil casos por ano, caindo, em média, para 460 casos por ano na década de 2000. A maior proporção ocorre na Região Nordeste e atinge, com maior frequência, a faixa etária entre 40 e 59 anos, seguida pela faixa acima de 60 anos de idade. Na década de 2000, foram registrados, em média, 141 óbitos por ano, com uma letalidade média anual de 31\%, considerada elevada quando comparada com a verificada nos países desenvolvidos (entre $10 \%$ e $17 \%$ ) (BRASIL, 2009).

\section{Infecções por Haemophilus influenzae tipo B}

Haemophilus influenzae tipo B (Hib) é uma bactéria causadora de diversas infecções que, na maioria das vezes, se iniciam no nariz e na garganta, mas podem afetar, também, outras partes do corpo, como ouvido, pulmões, pele, medula espinhal, cérebro e articulações. A doença de maior gravidade causada pela bactéria é a meningite, que atinge principalmente crianças menores de 5 anos de idade.

A suspeita de meningite causada pelo hemófilo se dá pelos sintomas neurológicos sem manifestações hemorrágicas. Os sintomas, iniciados subitamente, são febre, dor de cabeça intensa, náuseas, vômitos e rigidez de nuca. Em crianças menores de um ano, os sinais podem não ser tão evidentes. O diagnóstico é feito com exames laboratoriais do líquido cefalorraquidiano (LCR, liquor) e de sangue.

A transmissão do Haemophilus influenzae tipo B (Hib) ocorre através de contato de secreções da mucosa nasal de pessoa infectada com pessoas suscetíveis. O papel do portador é muito importante na transmissão, pois ele transmite a doença, mesmo sem apresentar os sinais e sintomas. 
O calendário vacinal infantil é apresentado no Capítulo 2, "O calendário de vacinação brasileiro e as estratégias para imunização da população" do livro Rede de Frio: gestão, especificidades e atividades (SILVA: FLAUZINO, 2016).
As complicações graves por Haemophilus influenzae (hemófilo) do tipo B decresceram em incidência desde a introdução da vacina DTP+Hib (tetravalente) no calendário infantil. Esse fato é demonstrado pela diminuição drástica da incidência de casos de meningite por essa bactéria, sobretudo na faixa etária dos menores de 2 anos de idade.

A única forma de prevenir a doença é a vacinação. A criança torna-se imunizada após a aplicação do esquema completo da vacina. Muitos países diminuíram drasticamente doenças como a meningite e a pneumonia causadas pela Hib com a implantação de programas abrangentes de vacinação. Atualmente, no Brasil, a prevenção das infecções graves pelo Haemophilus influenzae tipo B é realizada pela aplicação da vacina pentavalente $(\mathrm{DTP}+\mathrm{HiB}+$ hepatite $\mathrm{B})$ nas crianças menores de 12 meses.

\section{Infecção intestinal pelo rotavírus}

O rotavírus é o principal causador de diarreia infantil em crianças menores de 5 anos de idade, sendo que, nos prematuros e em crianças menores de 2 anos, ocorrem os casos mais graves e fatais. É responsável por cerca de $40 \%$ dos casos de gastroenterite aguda nessa faixa etária.

A população infantil é a mais afetada por não possuir um sistema imunológico eficiente para eliminar o vírus de seu organismo. A situação torna-se mais preocupante quando o rotavírus acomete crianças carentes, de baixa condição social, pois, pela falta de informação dos pais sobre a doença e pela dificuldade de acesso ao serviço de saúde, sofrem maior risco de morrer.

Existem sete sorotipos diferentes de rotavírus (um gênero de vírus com aspecto de roda), mas somente três deles infectam o homem e causam gastroenterite aguda. Essa variedade de sorotipos explica por que a pessoa pode ser infectada mais de uma vez, embora seja possível o desenvolvimento de certo grau de proteção cruzada, que torna mais leve a infecção por um tipo diferente de rotavírus. No entanto, é realmente a primeira infecção que costuma ser a mais grave.

A infecção por rotavírus pode ser assintomática, ou seja, pode não causar sintomas. Mas, em geral, as manifestações costumam aparecer, em média, dentro de três dias, podendo variar de um quadro leve, com diarreia líquida e duração limitada, a um quadro grave com desidratação, febre, vômitos e cólicas. O tempo de duração dos sintomas geralmente é de uma semana. Se não tratada, a rotavirose pode levar à morte. A forma clássica da doença, principalmente na faixa de 6 meses a 2 anos de idade, é caracterizada por uma forma abrupta de vômito, na maioria das vezes há diarreia e a presença de febre alta. 
As complicações da diarreia causada por rotavírus são devidas à desidratação e ao desequilíbrio hidroeletrolítico. E esse desequilíbrio hidroeletrolítico está relacionado, com frequência, à assistência e ao tratamento instituídos de forma imprópria, o que pode levar ao óbito do paciente.

Além dos cuidados com a higiene pessoal, doméstica e com alimentos, a prevenção da doença ocorre com a administração da vacina contra rotavírus pentavalente ou a vacina contra rotavírus monovalente em crianças menores de seis meses. Desde que essas duas formas da vacina começaram a ser administradas, os casos de diarreia por rotavírus diminuíram drasticamente.

Mesmo com os avanços obtidos na prevenção e no controle das doenças infecciosas, as doenças diarreicas são a segunda causa de morte na população de menores de 5 anos de idade, geram cerca de 1,8 milhões de óbitos a cada ano. Dentre essas doenças, as causadas pelo rotavírus contribuem com cerca de 600 mil óbitos, constituindo, assim, um dos principais problemas de saúde pública no mundo. Ressalta-se que a maioria das mortes ocorre em regiões menos desenvolvidas, em consequência da falta de saneamento básico e da desnutrição crônica, entre outros fatores.

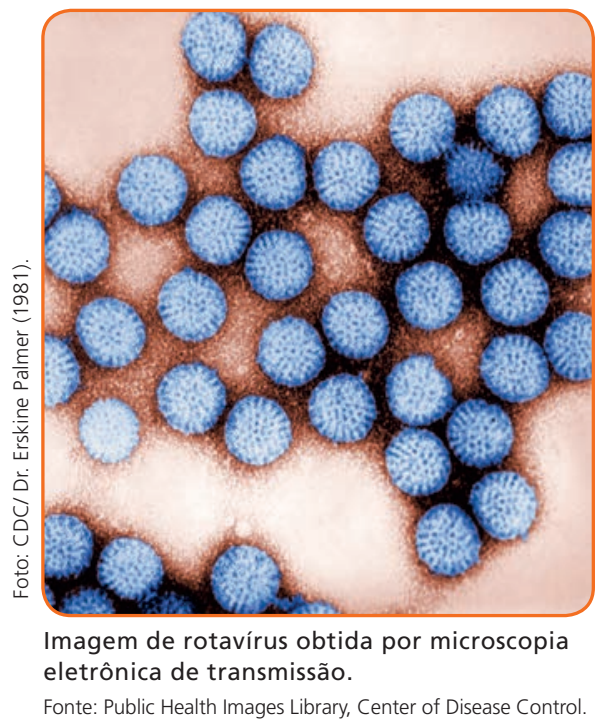

Dados do DATASUS estimam que crianças com idade de até 3 anos tenham 2,5 episódios de doença diarreica/ano e que $10 \%$ delas sejam causadas pelo rotavírus. Em locais onde a vacina não é aplicada, praticamente todas as crianças que chegam aos 5 anos de idade já foram infectadas pelo rotavírus. É importante ressaltar que a vacina de rotavírus é específica e protege somente contra a gastroenterite provocada por esse agente. O objetivo da vacinação é evitar as formas graves de diarreia.

A infecção pelo rotavírus não é de notificação compulsória, mas a vacinação foi uma das estratégias que reduziu drasticamente o número de casos, os quais, no país, eram documentados principalmente nas regiões com saneamento básico incipiente ou inexistente.

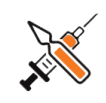

A vacina contra o rotavírus foi incluída no Calendário Nacional de Vacinação em 2006, com o intuito de reduzir o número de mortes e de internações de crianças. Estudos demonstraram que a vacina possui $85 \%$ de eficácia.
A notificação compulsória de algumas doenças foi abordada no Capítulo 6, "Vigilância epidemiológica", deste livro. 


\section{Doença pneumocócica invasiva}

O pneumococo ou Streptococcus pneumoniae é uma bactéria de grande importância epidemiológica por causar doenças pneumocócicas invasivas, como pneumonias, bacteremias (disseminação da bactéria pelo sangue), meningite, septicemia (infecção generalizada) e artrite, e não invasivas, como sinusite, otite média aguda, conjuntivite e bronquite.

As infecções pneumocócicas invasivas são muito graves, levam à hospitalização e, em muitos casos, à morte. Os pacientes de maior risco são os imunodeprimidos, os acamados, os neuropatas e os idosos.

É transmitido através de gotículas de secreções nasorrespiratórias de pessoas infectadas com a bactéria para pessoas suscetíveis. O papel do portador é de grande importância epidemiológica, pois ele transmite a bactéria sem apresentar sinais e sintomas da doença. Nesse caso, as crianças menores são os portadores mais frequentes. A melhor maneira de se proteger do pneumococo é por meio da vacinação.

Crie é o Centro de Referência de Imunobiológicos Especiais, uma estrutura que disponibiliza vacinas que não fazem parte do calendário básico de vacinação e que não estão acessíveis à população na rede básica de saúde.

Vacinas administradas no Crie são discutidas no Capítulo 2,

"O calendário de vacinação brasileiro e as estratégias para imunização da população", do livro Rede de Frio: gestão, especificidades e atividades (SILVA; FLAUZINO, 2016).
O pneumococo apresenta 90 sorotipos diferentes. Pesquisas para prevenir a infecção por essa bactéria foram aperfeiçoadas a fim de se identificar, laboratorialmente, quais os principais sorotipos causadores da doença invasiva e, com isso, chegar a um imunobiológico eficaz. A vacina atualmente disponível pelo PNI para as crianças tem uma composição 10 -valente, que inclui a proteção contra 10 sorotipos. Há também a vacina 23 -valente (contra 23 sorotipos), indicada para idosos e, em alguns casos, para as situações previstas nos Crie.

\section{Doença meningocócica}

A doença meningocócica é causada pela bactéria Neisseria meningitidis, que pode se instalar tanto no sistema nervoso quanto no sistema circulatório. Ao se instalar nas membranas que revestem o sistema nervoso central, provoca inflamação, originando a meningite. Quando se instala no sistema circulatório, provoca uma infecção generalizada denominada meningococcemia. É uma infecção aguda, de evolução rápida e, na maioria das vezes, fatal. Existem 13 sorogrupos identificados de Neisseria meningitidis, porém os que mais frequentemente causam doença são o A, B, C, Y e W135.

A transmissão da doença ocorre por meio de secreções respiratórias entre pessoas, principalmente através de portador assintomático. Na maioria dos casos, a bactéria permanece na orofaringe na pessoa receptora por curto período e acaba sendo eliminada pelos próprios mecanismos de defesa do organismo. Entretanto, em cerca de $1 \%$ das pessoas 
infectadas, a bactéria consegue penetrar na mucosa respiratória e atinge a corrente sanguínea, levando ao aparecimento da doença meningocócica. Ainda não são plenamente conhecidos os fatores que determinam ou mesmo favorecem essa situação. Vale ressaltar que a maioria dos portadores é composta por adolescentes e adultos jovens de camadas socioeconômicas menos privilegiadas.

O diagnóstico das meningites por meningococo é feito através dos sinais clínicos clássicos, além de exames de cultura do liquor para tipagem do meningogoco. A notificação do caso suspeito deve ser imediata para a vigilância epidemiológica, a fim de que sejam tomadas medidas de controle, como quimioprofilaxia dos comunicantes com o medicamento adequado.

A letalidade da doença varia de $7 \%$ a $70 \%$, dependendo da rapidez do diagnóstico e da assistência adequada. A ocorrência estimada é de cerca de 500 mil casos por ano no mundo, com cerca de 50 mil óbitos. Acomete, geralmente, crianças e adultos jovens; contudo, em epidemias, pode atingir pessoas de todas as faixas etárias.

No Brasil, a doença meningocócica é endêmica, com ocorrência de surtos esporádicos. Os coeficientes de incidência têm se mantido estáveis nos últimos anos, com aproximadamente 1,5 a 2,0 casos para cada 100 mil habitantes. Acomete indivíduos de todas as faixas etárias, porém aproximadamente $40 \%$ a $50 \%$ dos casos notificados ocorrem em crianças menores de 5 anos de idade. Os maiores coeficientes de incidência da doença são observados em lactentes, no primeiro ano de vida. Nos surtos e epidemias, observam-se mudanças nas faixas etárias afetadas, com aumento de casos entre adolescentes e adultos jovens.
Comunicante é qualquer pessoa ou animal que esteve em contato com pessoa ou animal infectado ou com ambiente contaminado, de modo a ter tido oportunidade de contrair a doença. O grau de contato do comunicante com o foco infeccioso influirá na maior ou menor possibilidade de transmissão da doença (BRASIL, 2009).

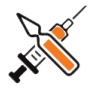

A letalidade da doença no Brasil situa-se em torno de $20 \%$ nos últimos anos. Na forma mais grave, de meningococcemia, a letalidade chega a quase $50 \%$.
Desde a década de 1990, os sorogrupos circulantes mais frequentes no Brasil são o $\mathrm{C}$ e o B. A partir de 2005, ocorreu aumento no número e na proporção de casos atribuídos ao sorogrupo $\mathrm{C}$ em diferentes regiões do país. Em meados de 2010, em virtude do aumento de circulação do sorogrupo $\mathrm{C}$ e da alta incidência da doença observada em crianças, a vacina meningocócica conjugada contra o sorogrupo $\mathrm{C}$ foi introduzida no calendário de vacinação da criança.

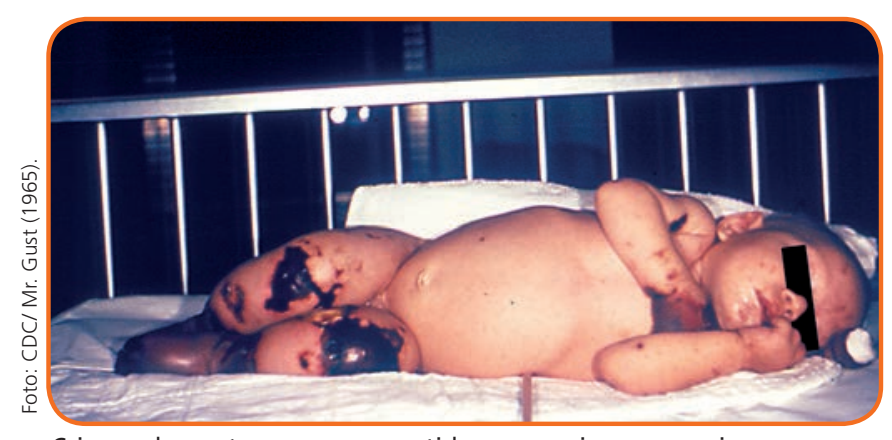

Criança de quatro meses acometida por meningococcemia, apresentando manchas pelo corpo e gangrena nas mãos e nos pés. Fonte: Public Health Images Library, Center of Disease Control. 


\section{Poliomielite}

Causada pelos poliovírus selvagens I, II e III, a poliomielite (também conhecida como paralisia infantil) é caracterizada por paralisia flácida aguda progressiva, iniciada geralmente nos membros inferiores, com risco de progressão até o diafragma e consequente morte da pessoa. Os indivíduos mais suscetíveis são os que têm até 15 anos de idade.

A transmissão da doença ocorre por contato direto pessoa a pessoa, pela via fecal-oral (mais frequentemente), por objetos, alimentos e água contaminados com fezes

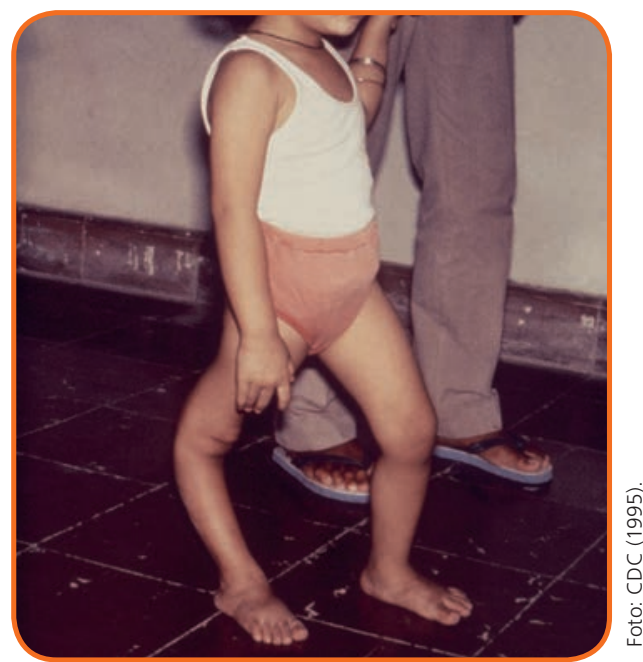

Criança apresentando uma deficiência na perna causada por poliomielite. Depois de inoculação orofaríngea, o vírus se multiplica e circula pela corrente sanguínea, alcançando o sistema nervoso central. Lá, ele infecta nervos ligados às funções motoras, causando paralisia.

Fonte: Public Health Images Library, Center of Disease Control. de doentes ou portadores, ou pela via oral-oral, através de gotículas de secreções da orofaringe (ao se falar, tossir ou espirrar). A falta de saneamento, as más condições habitacionais e a higiene pessoal precária constituem fatores que favorecem a transmissão do poliovírus.

A infecção pelo poliovírus selvagem apresenta-se sob diferentes formas clínicas:

* Forma inaparente ou assintomática - pode ser identificada apenas por exames laboratoriais específicos. Ocorre em 90\% a 95\% das infecções.

* Forma abortiva - caracteriza-se por sintomas inespecíficos: febre, cefaleia, tosse, coriza e manifestações gastrintestinais, como vômito, dor abdominal e diarreia. Como na forma inaparente, só é possível estabelecer diagnóstico por meio do isolamento do vírus. Ocorre em cerca de $5 \%$ dos casos.

* Forma meningite asséptica - no início, apresenta-se com as mesmas características da forma abortiva. Posteriormente, surgem sinais de irritação meníngea e rigidez de nuca. Ocorre em cerca de $1 \%$ das infecções.

* Forma paralítica - acomete em torno de 1\% a 1,6\% dos casos, e apenas as formas paralíticas possuem características clínicas típicas, que permitem sugerir o diagnóstico de poliomielite. 
Para a vigilância epidemiológica, define-se caso suspeito de poliomielite quando, subitamente, ocorre uma paralisia flácida (não espástica, sem rigidez muscular) aguda, em indivíduos com menos de 15 anos de idade. Como medida de vigilância epidemiológica, está indicada a profilaxia pré-exposição, por exemplo, para um viajante a um dos países onde a doença é endêmica ou não foi erradicada. Mediante aglomerados de casos, está indicada a vacinação de bloqueio.

A doença foi eliminada no Brasil, como consequência das estratégias adotadas de intensificação da vacinação e da realização das campanhas nacionais anuais de vacinação, desde 1980. No entanto, a vacinação regular no calendário vacinal infantil e as campanhas de atualização são mantidas, porque a poliomielite ainda ocorre em caráter endêmico em alguns países, tais como algumas regiões da Índia, Paquistão, Afeganistão e Nigéria (ou seja, o agente ainda existe em outros lugares e pode chegar até aqui, desencadeando casos da doença).

\section{Rubéola}

Doença infectocontagiosa aguda, causada por um vírus, possui alta contagiosidade e acomete, principalmente, crianças. Sua importância epidemiológica está relacionada ao risco de abortos, natimortos. É particularmente perigosa na forma congênita (Síndrome da Rubéola Congênita - SRC), pois, nesse caso, pode deixar sequelas irreversíveis no feto, como glaucoma, catarata, malformação cardíaca, retardo no crescimento, surdez e outras.

A transmissão acontece de uma pessoa a outra, geralmente pela emissão de gotículas das secreções respiratórias dos doentes. Seus sinais característicos são febre baixa, surgimento de gânglios linfáticos e de exantemas, que se espalham primeiro pelo rosto e depois pelo resto do corpo. Como seus sinais e sintomas são comuns a outras infecções, pode ser confundida com outras doenças, o que dificulta seu diagnóstico. É autolimitada, apresentando, em sua maioria, quadro sem gravidade. Durante a gravidez, a transmissão para o feto é pela via transplacentária, após a viremia (circulação do vírus no sangue) materna.

A imunidade da doença é adquirida com a vacinação ou pela infecção natural, que é duradoura e permanece praticamente por toda vida. A vacina tríplice viral, que protege contra a rubéola, o sarampo e a caxumba, é especialmente indicada para crianças. Os adolescentes e adultos, em especial as mulheres que não tiveram contato com a doença, também, devem tomar a vacina.
No Brasil, a consolidação da vigilância epidemiológica em níveis nacional e estadual, com bases técnicas e operacionais, possibilitou o desenvolvimento de ações de impacto no controle de doenças evitáveis por imunizações O seu principal êxito foi o controle da poliomielite no Brasil, na década de 1980, o que abriu perspectivas para a erradicação da doença no continente americano em 1994.

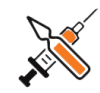

A vacinação é essencial para diminuir a circulação do vírus da rubéola. 
A vigilância e o combate da rubéola foram impulsionados pela implementação do Plano de Erradicação do Sarampo no país, em 1999, que impulsionou a vigilância e o controle da doença. Em 2008, ocorreu, no Brasil, a maior Campanha de Vacinação contra Rubéola do mundo, com 65,9 milhões de pessoas vacinadas na faixa etária de 19 a 39 anos de idade. A campa-

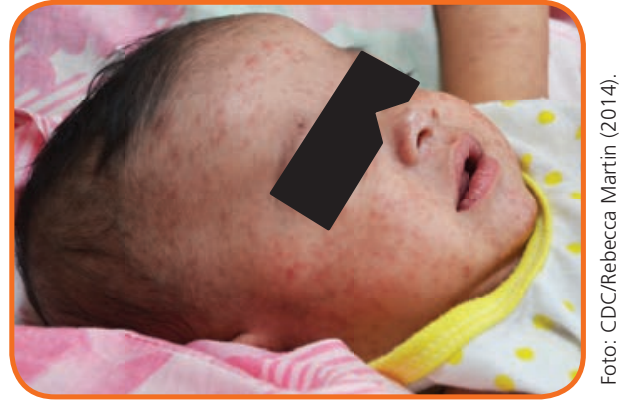

Bebê acometido pelo vírus da rubéola apresentando rash cutâneo.

Fonte: Public Health Images Library, Center of Disease Control. nha alcançou uma cobertura vacinal de $94 \%$.

Diante dos esforços realizados para controlar essa doença, o Brasil cumpriu a meta de eliminação da rubéola e da SRC até o ano de 2010. Entre 2010 e 2014, não se registraram casos da doença.

\section{Sarampo}

O sarampo, uma doença contagiosa causada por um vírus e até recentemente muito comum na infância, é extremamente contagioso, e sua transmissão ocorre de forma direta de pessoa a pessoa, por meio das secreções nasofaríngeas e, também, pela dispersão de gotículas com partículas virais no ar, em ambientes fechados, como escolas, creches e clínicas.

Os sintomas iniciais são febre, tosse persistente, irritação ocular e corrimento do nariz. Posteriormente, surgem manchas avermelhadas por todo o corpo, iniciando no rosto, que progridem em direção aos pés, com duração mínima de três dias. De acordo com a evolução, podem surgir complicações como otite, pneumonia, convulsões, lesão cerebral e até a morte.

Acredita-se que as complicações sejam desencadeadas pelo próprio vírus do sarampo, que, na maior parte das vezes, atinge mais gravemente os desnutridos, os recém-nascidos, as gestantes e as pessoas portadoras de imunodeficiências.

O tratamento do sarampo é sintomático; o diagnóstico é feito mediante:

*⿻x. exame em amostras de sangue colhidas em período oportuno (até 28 dias após o início do exantema); e

* análise de swab de nasofaringe, orofaringe e exame de urina, visando a detecção viral, coletados oportunamente, em conformidade com os prazos adequados à notificação do caso. 
A vigilância epidemiológica do sarampo, assim como a de qualquer doença inserida em um pacto de compromisso de erradicação internacional, deve ser realizada com alta qualidade e sensibilidade. Assim, todo caso suspeito deve ser notificado e investigado criteriosamente, tanto para se identificar a fonte quanto para prevenir a disseminação dos casos, com o uso da vacinação de bloqueio.

A faixa etária de maior risco são os indivíduos entre 6 meses e 39 anos de idade. Em relação aos adultos, os trabalhadores de portos e aero-

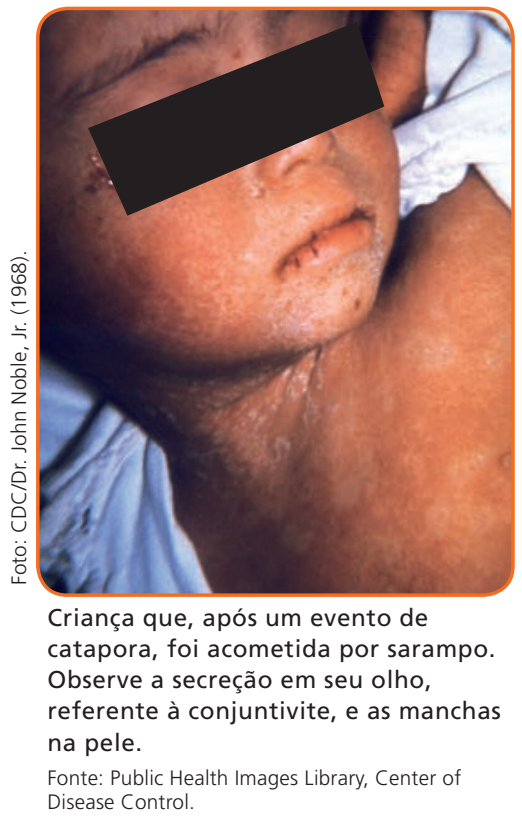
portos, hotelaria e profissionais do sexo apresentam maiores chances de contrair sarampo, pela maior exposição a indivíduos de outros países que não adotam a mesma política intensiva de controle da doença.

Para a prevenção das crianças, é fornecida a vacina triviral, que protege contra rubéola, sarampo e caxumba. Já os adolescentes e adultos, principalmente os pertencentes ao grupo de risco, devem tomar a vacina tríplice viral ou dupla viral (contra sarampo e rubéola). Desde a década de 1990, o Brasil tem realizado estratégias de vacinação e outras medidas que têm conseguido manter a doença sob controle.

\section{Parotidite infecciosa}

A parotidite infecciosa é conhecida popularmente por caxumba ou papeira. É causada por um vírus que provoca inflamação das glândulas parótidas; e, eventualmente, mediante complicações, pode causar otite, conjuntivite, sinusite e até mesmo orquite (inflamação dos testículos).

Não se trata de uma doença imunoprevenível de grande magnitude ou relevância; seu curso é autolimitado, e sua evolução, benigna. Sua vigilância se restringe ao monitoramento da cobertura com a vacinação incluída na tríplice e na quádrupla virais e à identificação de surtos para contenção com bloqueio vacinal.

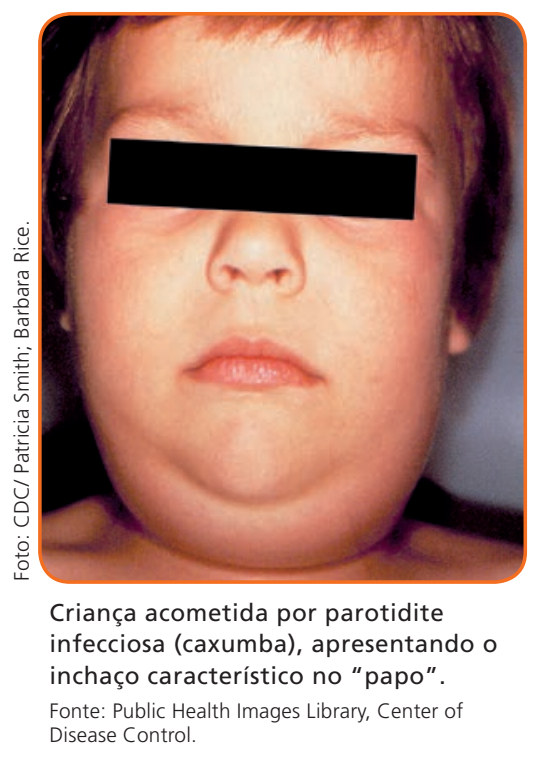




\section{Varicela}

A varicela, causada pelo vírus varicella-zoster, é uma doença altamente contagiosa, que acomete, principalmente, crianças e é transmitida pelo contato do vírus presente nas secreções respiratórias de uma pessoa doente a outra suscetível.

O principal sintoma da doença é a presença de vesículas ou bolhas, de conteúdo claro e com as bordas avermelhadas, que se disseminam por todo corpo, inclusive boca, mucosas e couro cabeludo. Acompanha febre baixa ou moderada de curta duração, em média, de quatro dias. $\mathrm{Na}$ evolução da doença, as lesões apresentam-se em vários estágios diferentes ao mesmo tempo: vesículas com conteúdo claro, às vezes um pouco mais turvo e outras com crostas secas.

A varicela pode evoluir de forma grave e progressiva, com formação de novas lesões e risco de disseminação da doença. Ela causa, entre outras complicações, a encefalite, a hepatite e a pneumonia, podendo levar a óbito. Crianças menores de 1 ano de idade, adultos, gestantes e imunodeprimidos têm maior risco de desenvolver complicações, correspondendo à maior proporção dos casos graves registrados. A infecção materna no primeiro ou no segundo trimestre de gestação pode resultar em malformações no embrião (embriopatia).

Não há dados consistentes sobre a incidência de varicela no Brasil. Entretanto, a estimativa é de cerca de 3 milhões de casos ao ano. A análise das internações por faixa etária demonstra que estas se concentram em crianças de 1-4 anos de idade, seguindo-se as crianças com menos de 1 ano e de 5-9 anos de idade, respectivamente. Embora o maior número absoluto de hospitalizações seja observado entre crianças, grupo em que se espera o maior número de casos da doença, proporcionalmente, os adultos apresentam maior risco de evoluir com complicações, hospitalização e óbito.

O coeficiente de mortalidade varia de $0,4 \%$ a $0,7 \%$. A taxa de letalidade entre os casos hospitalizados varia de acordo com a idade, chegando a 4,6\% na faixa etária de 50 anos ou mais e a 2,6\% na faixa etária de 15 a 49 anos (BRASIL, 2009).

A vacina está no Calendário Nacional de Vacinação do SUS, compondo a tetraviral, que também protege contra sarampo, caxumba e rubéola. Na rede pública, é oferecida, de rotina, aos 15 meses de idade para as crianças que receberam a vacina tríplice viral (sarampo, caxumba e rubéola) entre 12 e 14 meses de idade. Ela deve reduzir cerca de $80 \%$ das hospitalizações por varicela. 
Com a inclusão da vacina contra a varicela no calendário básico de vacinação infantil, a vigilância epidemiológica objetiva:

* reduzir a incidência de todas as formas de varicela;

reduzir a intensidade da varicela nos indivíduos vacinados;

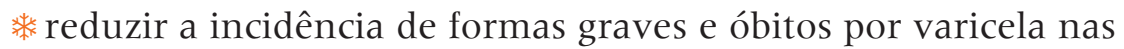
crianças acometidas;

* promover proteção indireta para indivíduos suscetíveis não vacinados, pela manutenção de altas coberturas vacinais (imunidade de rebanho); e

* reduzir o número de internações e custos relacionados à hospitalização por formas moderadas e graves de varicela.

\section{Gripe}

Conhecida como gripe, é uma doença viral febril, aguda, geralmente benigna e autolimitada. Caracterizada por início abrupto de sintomas como febre, calafrios, tremores, dor de cabeça, mialgia e anorexia, assim como sintomas respiratórios com tosse seca, dor de garganta e coriza.

Os vírus Influenza são transmitidos por pessoas infectadas ao tossir ou espirrar. Dos três tipos de vírus Influenza, A, B e C, o vírus C origina infecções respiratórias brandas e não possui impacto na saúde pública, nem está relacionado com epidemias. Já os vírus Influenza A e B são responsáveis por epidemias sazonais, sendo que o vírus Influenza A é responsável pelas grandes pandemias. Os vírus Influenza A são classificados em subtipos, entre estes os subtipos A (H1N1) e A (H3N2) são os que circulam atualmente em humanos.

Idosos, gestantes, pessoas com comorbidade e crianças possuem maior risco de desenvolver complicações devidas à Influenza. A vacinação é a intervenção mais importante na redução do impacto da doença e é um componente-chave para controlar a circulação de vírus.

O Ministério da Saúde realiza a Campanha Nacional de Vacinação contra Influenza para os grupos prioritários que recebem, gratuitamente, a vacinação nos postos de saúde. Os grupos prioritários a serem vacinados, de acordo com recomendações do Ministério da Saúde, são:(BRASIL, 2009).

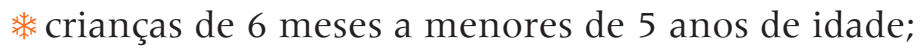

落 gestantes;

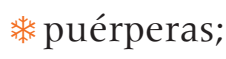

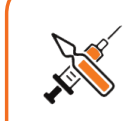

Por causa das mudanças dos vírus circulantes, faz-se necessária a vacinação anual contra a doença. 
* trabalhador da saúde;

*ovos indígenas;

* indivíduos com 60 anos ou mais de idade;

* população privada de liberdade;

* funcionários do sistema prisional;

* pessoas portadoras de doenças crônicas não transmissíveis;

* pessoas portadoras de outras condições clínicas especiais (doença respiratória crônica, doença cardíaca crônica, doença renal crônica, doença hepática crônica, doença neurológica crônica, diabetes, imunossupressão, obesos, transplantados e portadores de trissomias).

Não é doença de notificação compulsória, a menos que ocorra em surtos. Sua principal estratégia de vigilância é o monitoramento dos tipos de vírus Influenza circulante, por meio das atividades realizadas nas unidades sentinelas. Essas unidades captam sintomáticos respiratórios e analisam amostras de tecido nasofaríngeo e orofaríngeo, buscando identificar, por meio de técnicas de biologia molecular, quais os tipos circulantes. Com base na identificação desses tipos, as cepas vacinais são atualizadas anualmente.

\section{Febre amarela}

Doença infecciosa causada por vírus e transmitida por vetores. Possui início abrupto com febre alta, calafrios, cansaço, dor de cabeça, dor muscular, náuseas e vômitos. A maioria dos infectados se recupera bem e adquire imunização permanente contra a doença. Sua forma mais grave é rara e costuma aparecer após um breve período de bem-estar, quando podem ocorrer insuficiências hepática e renal, icterícia (olhos e pele amarelados), manifestações hemorrágicas e cansaço intenso.

É transmitida por mosquitos em áreas urbanas e silvestres, contudo sua manifestação é idêntica nos dois casos de transmissão, já que o vírus e a evolução clínica são os mesmos. O que os diferencia são os transmissores. O mosquito transmissor em área urbana é o Aedes aegypti (o mesmo da dengue) e, em área silvestre, os mosquitos Haemagogus e Sabethes. A transmissão ocorre quando uma pessoa suscetível, que nunca tenha tomado a vacina ou tido a doença, circula em áreas silvestres e é picada por um mosquito infectado com o vírus. Os macacos são o principal reservatório do vírus nas áreas silvestres. Não há transmissão pessoa a pessoa. 
Além dos cuidados com o ambiente, a vacinação é a conduta para prevenção da doença, principalmente para os viajantes que irão se deslocar para áreas onde haja a circulação do vírus.

O diagnóstico é sorológico, e como se trata de doença febril íctero-hemorrágica, é importante que os profissionais dos diversos níveis de atenção estejam preparados para suspeitar de formas graves agudas de hepatites, leptospirose e dengue, no diagnóstico diferencial com febre amarela.

A vigilância da febre amarela é um trabalho extremamente integrativo: a vigilância ambiental monitora as epizootias, ou seja, doenças que ocorrem em animais, principalmente em primatas não humanos; a vigilância epidemiológica mantém-se em constante articulação com a vigilância ambiental para monitorar o comportamento da febre amarela na população.

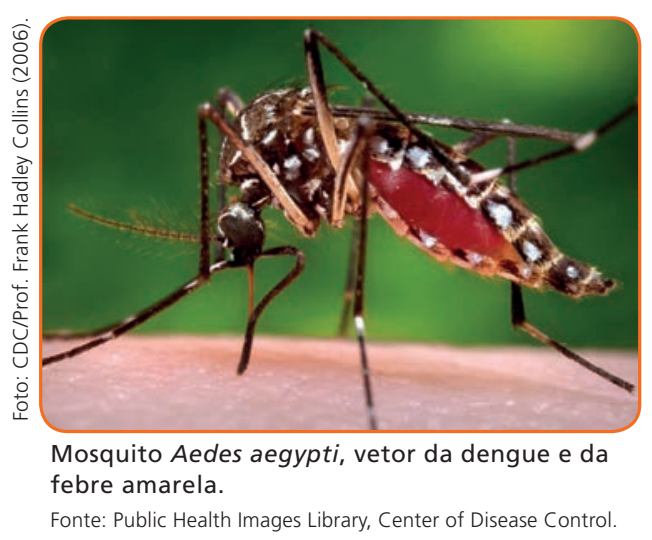

A doença reveste-se da maior importância epidemiológica por sua gravidade clínica e elevado potencial de disseminação em áreas urbanas. Desde 1942, não há registro no Brasil da forma de transmissão pelo Aedes aegypti (ciclo urbano) da febre amarela. Os casos confirmados após 1942 são resultado de transmissão silvestre.

\section{Raiva humana}

A raiva é uma antropozoonose, transmitida ao homem pela inoculação do vírus presente na saliva e nas secreções do animal infectado, principalmente por mordedura e lambedura. Caracteriza-se como uma encefalite progressiva e aguda que apresenta letalidade de aproximadamente $100 \%$. A doença apresenta dois principais ciclos de transmissão: urbano e silvestre, sendo o urbano passível de eliminação, por se disporem de medidas eficientes de prevenção, tanto em relação ao ser humano quanto à fonte de infecção.

É transmitida por lesões provocadas pelo ataque ou pela defesa de animais:

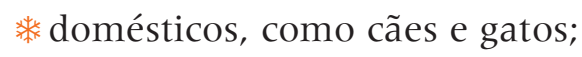

mantidos para abate e consumo, como bovinos; e

Antropozoonose é uma doença que pode ocorrer entre seres humanos e animais de outras espécies. 
* animais silvestres que recebem a visita de humanos em seu habitat, ou que, em função da ocupação de seu ambiente de origem, se adaptam a acomodações urbanas, como os morcegos, frugívoros ou hematófagos.

A transmissão ocorre quando o vírus, contido na saliva do animal infectado, penetra no organismo humano, multiplica-se no local da mordedura, arranhadura ou lambedura e atinge o sistema nervoso periférico e, posteriormente, o sistema nervoso central. A partir daí, dissemina-se para vários órgãos e glândulas salivares, onde também se replica, sendo eliminado pela saliva de pessoas ou animais doentes (BRASIL, 2014).

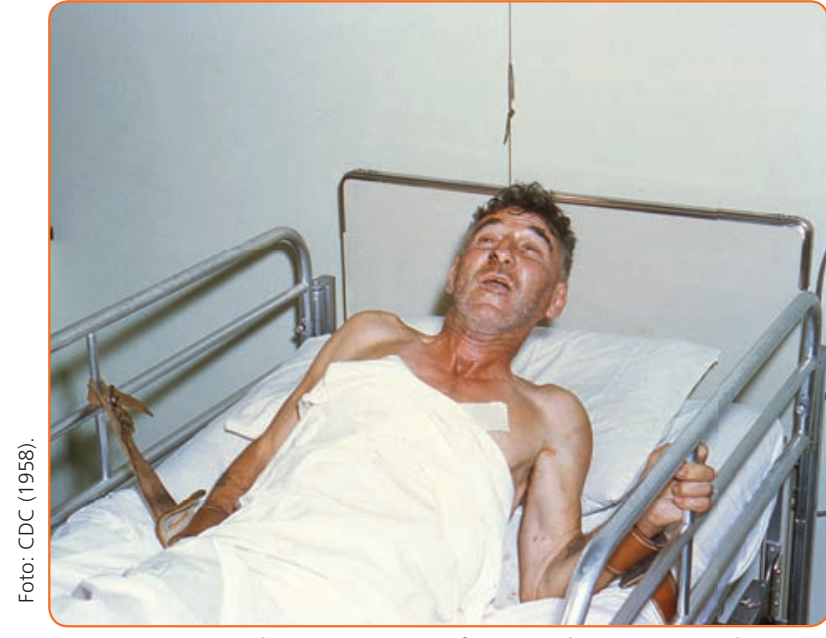

Paciente acometido por raiva. Conforme a doença progride, aparecem sintomas neurológicos, dentre eles: insônia, ansiedade, confusão, paralisia leve, alucinações, agitação, hipersalivação, dificuldade para engolir, hidrofobia e, por fim, morte.

Fonte: Public Health Images Library, Center of Disease Control.
A vigilância da raiva se dá com profilaxia pré ou pós-exposição. A profilaxia pré-exposição é indicada mediante risco ocupacional, ao qual estão submetidos bombeiros, médicos veterinários, guardas florestais etc. A vigilância ambiental é uma importante parceira nas ações de controle da população de animais transmissores.

Na profilaxia da raiva humana, na conduta pós-exposição, ou seja, após acidentes com risco de transmissão da raiva, é essencial considerar: a possibilidade de observar o animal envolvido no acidente e a avaliação da localização e da gravidade da lesão. Deve-se recomendar que o animal envolvido no acidente não seja abatido, para que seja observada a sua evolução por, pelo menos, 10 dias, período de incubação da raiva.

No Brasil, a raiva é endêmica, com grandes variações entre as regiões do país. Até 2005, dezenas de casos de raiva humana eram registrados anualmente. A partir de 2006, o número de casos caiu para um dígito e vem se mantendo nessa faixa. Os últimos casos de raiva humana transmitida por cão ou gato ocorreram em 1981, na Região Sul; em 2001, nas regiões Sudeste e Centro-Oeste; em 2004, na Região Norte; e, mais recentemente, em 2013, na Região Nordeste. No ano de 2014, foi alcançada a meta de zero casos, uma vez que não houve registro de raiva humana causada por cão ou gato, com as respectivas variantes citadas. 


\section{Acidentes com animais peçonhentos}

Acidentes com animais peçonhentos, apesar de não serem imunopreveníveis, devem ser tratados com a máxima urgência com imunobiológicos, os chamados soros antipeçonhentos. O Brasil é uma referência internacional na produção desses imunobiológicos, especialmente pelos Institutos Vital Brazil (RJ) e Butantã (SP) e pela Fundação Ezequiel Dias (MG).

Ao contrário do que se imagina, os acidentes com animais peçonhentos não são raros no país, com sua fauna exuberante e diversa. Há serpentes venenosas de distribuição variada (jararacas, surucucus, cascavéis, corais verdadeiras), bem como aracnídeos (aranhas e escorpiões), lagartas de venenos letais (taturanas, marandovás) e uma série de outros animais que, picando, atacam ou se defendem da presença humana.

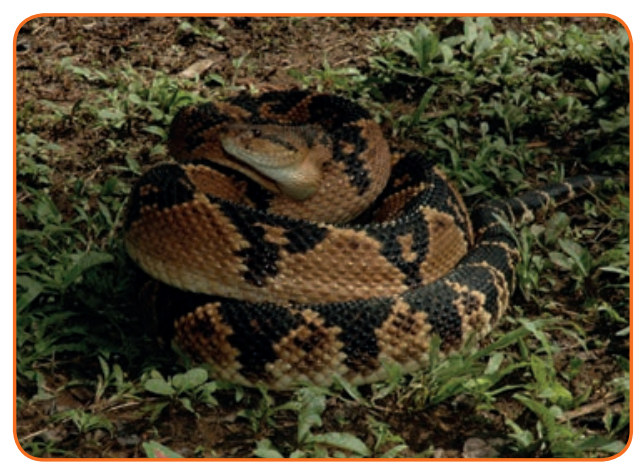

Lachesismuta, mais conhecida como surucucubico-de-jaca. Segundo o Instituto Vital Brazil, é a maior serpente peçonhenta das Américas, podendo alcançar 4 metros de comprimento.

Fonte: Extraída do site http://www.vitalbrazil.rj.gov.br/cobras venenosas.html (2015).

profissionais no tratamento, o qual pode variar desde uma observação temporária até a hospitalização duradoura, dependendo da gravidade do acidente e do tempo decorrido entre este e o devido socorro.

\section{Papilomavírus humano}

Estudos comprovaram que a presença do papilomavírus humano (HPV) é a condição necessária para o câncer de colo do útero, que é um grande problema de saúde pública por sua alta incidência e mortalidade.

O HPV é um vírus que apresenta mais de 150 genótipos diferentes, sendo que os principais tipos relacionados ao câncer do colo do útero são os HPV 6, 11, 16 e 18. A principal forma de transmissão do HPV é por via sexual. Entre as estratégias para a prevenção da doença, além
Turismo ecológico, visitas a ambientes inóspitos, culturas agrícolas, intempéries e, principalmente, ocupação desordenada causam perturbações no habitat dos animais, que, por sua vez, atacam como forma de defesa. Além disso, estes são forçados a procurar ambientes urbanos para se alimentar, reproduzir e, portanto, viver. 
da detecção precoce, está a vacinação, o uso de preservativo e ações educativas.

Em 2014, o Ministério da Saúde ampliou o Calendário Nacional de Vacinação com a introdução da vacina quadrivalente contra o papilomavírus humano (HPV) no Sistema Único de Saúde (SUS); essa vacina confere proteção contra HPV 6, 11, 16 e 18.

A população-alvo da vacinação é composta por adolescentes do sexo feminino, na faixa etária entre 9 e 13 anos de idade. Essa faixa etária foi adotada porque a vacina tem maior evidência de proteção para pessoas que nunca tiveram contato com o vírus.

Conjuntamente com as atuais ações para o rastreamento do câncer do colo do útero, a vacinação possibilitará, nas próximas décadas, prevenir essa doença, que representa, hoje, a quarta principal causa de morte por neoplasias entre mulheres no Brasil (BRASIL, 2014).

\section{Considerações finais}

A importância do controle das doenças transmissíveis foi reportada pelos inúmeros relatos de pandemias (como o cólera) e epidemias (como a peste e a varíola) que assolaram o mundo. O que é importante ressaltar aqui é que grande parte delas foi controlada através de estratégias de vigilância e de vacinação.

A imunização é potente porque existem pessoas que lhe permitem ser potente. Se não houvesse um rígido controle do imunobiológico em toda a cadeia de produção e na rede de frio, não seria possível a ação de tão elevada importância como a vacinação. No entanto, não é a única medida necessária para a vigilância epidemiológica das doenças transmissíveis. As notificações e os mecanismos de monitoramento da ocorrência de casos dessas doenças, as políticas públicas voltadas para agir sobre os determinantes das doenças transmissíveis e o desenvolvimento científico e tecnológico são de fundamental importância para o controle dessas doenças e para a manutenção da saúde de uma população.

Alguns exemplos de desdobramentos desses itens em ações são:

* Ampliar o espectro das políticas de saneamento básico com aumento da oferta de água potável, para a consolidação e a sustentabilidade do controle de um conjunto diverso de problemas que atinge, em especial, a população de crianças. Esse é o caso das diarreias causadas por agentes de transmissão oral-fecal - as helmintoses intestinais; a esquistossomose; a hepatite A; a leptospirose e outras. 
* Melhorar o espaço das cidades (habitação, higiene, água, esgoto, outros) também como forma de agir sobre outras doenças de importância no contexto urbano, resultantes da transmissão por contato interpessoal, como a tuberculose e a hanseníase, ou por outras vias, como a leptospirose.

* Fortalecer a atenção primária à saúde, com a ampliação do acesso universal a todas as faixas populacionais e regiões, possibilitando, pelo tratamento precoce e efetivo, influir e impactar o curso de uma série de doenças, como diarreias, infecções respiratórias, tuberculose, hanseníase, malária.

* Ampliar o desenvolvimento de inovações biotecnológicas, como vacinas e medicamentos, para acelerar o controle de algumas doenças, tais como dengue, leishmaniose visceral, ou consolidar o controle de outras, como AIDS, malária, tuberculose, hanseníase.

\section{Referências}

BARRETO, M. L. Esboços para um cenário das condições de saúde da população brasileira 2022/2030. In: FUNDAÇÃO OSWALDO CRUZ. A saúde no Brasil em 2030: prospecção estratégica do sistema de saúde brasileiro: população e perfil sanitário. Rio de Janeiro: Fiocruz: Ipea: Ministério da Saúde: Secretaria de Assuntos Estratégicos da Presidência da República, 2013. v. 2, p. 97-120.

BRASIL. Ministério da Saúde. Secretaria de Atenção à Saúde. Departamento de Atenção Básica. Vigilância em saúde: zoonoses. Brasília, DF, 2009.

BRASIL. Ministério da Saúde. Secretaria de Vigilância em Saúde. Guia de vigilância em saúde. Brasília, DF, 2014

BRASIL. Ministério da Saúde. Secretaria de Vigilância em Saúde. Guia de vigilância epidemiológica. 7. ed. Brasília, DF, 2009.

BRASIL. Ministério da Saúde. Secretaria de Vigilância em Saúde. Departamento de Vigilância de Doenças Transmissíveis. Coordenação-geral do Programa Nacional de Imunizações. Informe técnico sobre a vacina papilomavírus humano (HPV) na atenção básica. Brasília, DF, 2014.

BRASIL. Ministério da Saúde. Secretaria Nacional de Ações Básicas de Saúde. Divisão Nacional de Organização de Serviços de Saúde. Terminologia básica em saúde. Brasília, DF: Centro de Documentação, 1983.

CHERKASSKII, B. L. The system of the epidemic process. Journal of Hygiene and Epidemiology, v. 32, p. 321-328, 1988.

FUNDAÇÃO NACIONAL DE SAÚDE (Brasil). Manual de normas de vacinação. 3. ed. Brasília, DF, 2001.

NASCIMENTO-CARVALHO, C. M.; ANDRADE A. L. S. S. Vacinação contra Haemophilus influenzae tipo b: proteção a longo prazo. Jornal de Pediatria, Porto Alegre, v. 82, p. 109-114, 2006. Suplemento 3. 
ORGANIZACIÓN PANAMERICANA DE LA SALUD. Principios de epidemiologia para el control de enfermedades. 1983. Mimeografado.

ROUQUAYROL, M. Z.; SILVA, M. G. C. Epidemiologia \& saúde. 7. ed. Rio de Janeiro: Medbook, 2013.

SILVA, M. N.; FLAUZINO, R. F. (Org.). Rede de frio: gestão, especificidades e atividades. Rio de Janeiro: Ed. Fiocruz, 2016. No prelo.

VIRCHOW, R. Collected essays on public health and epidemiolgy, v. 1. New York: Science History Publ., 1985.

WALDMAN, L. A.; SILVA, L. J.; MONTEIRO, C. A. Trajetória das doenças infecciosas: da eliminação da poliomielite à reintrodução da cólera. Informe Epidemiológico do SUS, Brasília, DF, v. 8, n. 3, p. 5-47, 1999. 


\section{Anexo A - Conceitos básicos em epidemiologia das doenças transmissíveis}

Abordaremos agora alguns conceitos básicos relacionados com o processo saúde-doença, o que proporcionará melhor embasamento sobre a vigilância de doenças imunopreveníveis. Para isso, adotamos um estilo descritivo, de caráter explicativo e ilustrado com exemplos, um recurso didático para facilitar o entendimento dos temas e tornar a leitura mais agradável. Temos certeza de que o resultado desse estudo será útil nas suas atividades.

\section{Doenças transmissíveis: denominações}

A primeira definição de que precisamos é: o que é uma doença transmissível?

Doença transmissível é aquela causada por um agente infeccioso específico ou seus produtos tóxicos, a qual se manifesta pela transmissão desse agente ou seus produtos:

燐 diretamente de uma pessoa ou animal infectado para outro; ou

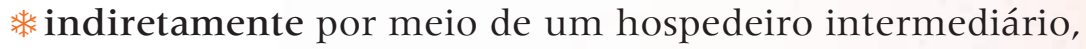
de natureza vegetal ou animal, de um vetor, ou por meio de ambiente inanimado (ORGANIZAÇÃO PAN-AMERICANA DA SAÚDE, 1983).

Por exemplo: a Aids, causada pelo HIV, é uma doença transmissível diretamente; já a dengue é uma doença transmissível indiretamente, pois o vírus depende de um mosquito como vetor para introduzi-lo em uma pessoa.

Doença contagiosa é aquela em que o agente etiológico se difunde através do contato direto com os indivíduos infectados. Por exemplo, sarampo e rubéola transmitidos por secreções da orofaringe e as doenças sexualmente transmissíveis (DSTs).

Toda doença contagiosa é infecciosa, mas o inverso não é verdadeiro. Por exemplo, tétano é causado pelo bacilo tetânico, quando uma pessoa é infectada por ele; no entanto, essa pessoa não transmite tétano para ninguém.
Esta escolha de estruturação facilita a sua consulta sempre que tiver dúvidas sobre o significado de algum termo. 


\section{Agente biológico (etiológico)}

Agente biológico é um ser vivo que pode ser introduzido em outro ser vivo no qual é capaz de se desenvolver e/ou se multiplicar e, dependendo do estado do hospedeiro, pode ou não gerar uma doença infecciosa transmissível. O agente biológico pode assumir várias formas durante seu ciclo reprodutivo; diversos agentes podem ser transmitidos em diferentes fases desse ciclo.

Existem seis categorias básicas de agentes biológicos específicos:
protozoários;
燐 helmintos;
米 bactérias;
橉 vírus;
莼 fungos;
rickettsias.
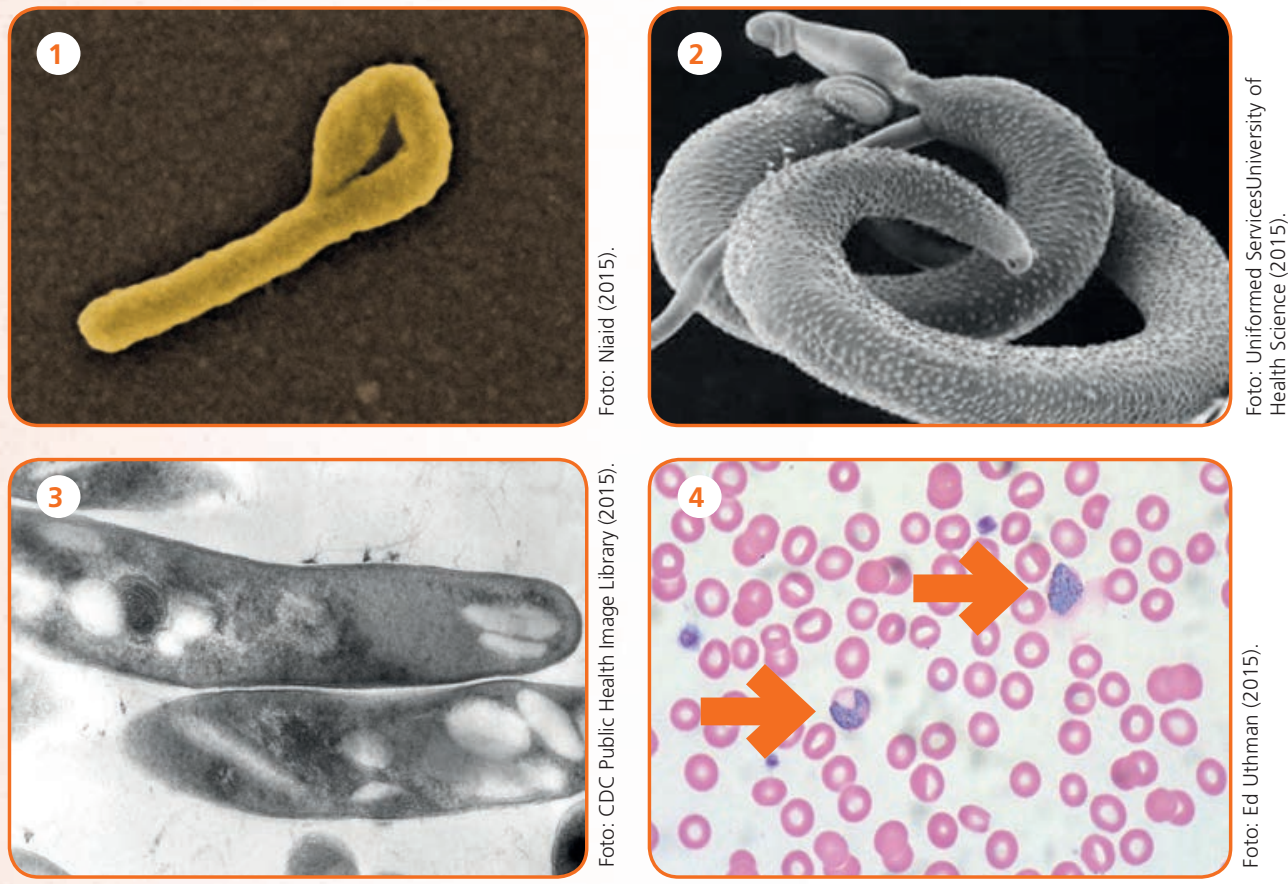

Imagens obtidas por diferentes técnicas de microscopia mostrando agentes patológicos que representam quatro das seis categorias descritas no texto: (1) vírus Ebola, causador da doença de mesmo nome; (2) Schistosoma mansoni, helminto causador da esquistossomose; (3) Mycobacterium tuberculosis, o bacilo de Koch - bactéria causadora da tuberculose; (4) Plasmodium vivax (destacado com as setas), protozoário causador da malária presente no sangue de uma pessoa acometida. Fonte: WikimediaCommons. 
Independentemente da categoria, as espécies capazes de produzir doença humana são denominadas de agentes patogênicos, patógenos ou agentes infecciosos. Os agentes patogênicos possuem características que regem a sua relação com o hospedeiro (o que será discutido mais adiante) e que contribuem para o aparecimento da doença como produto dessa relação. São elas:

* Infectividade - capacidade de o agente invadir o hospedeiro, seja homem ou animal, e ali permanecer multiplicando-se e/ou desenvolvendo-se. Independentemente da gravidade da doença. Por exemplo, gripe (alta) x fungos em geral (baixa).

*⿻ Patogenicidade - é a capacidade de o agente infeccioso, uma vez instalado no organismo do homem e de outros animais, produzir sintomas em maior ou menor proporção entre os hospedeiros infectados. Por exemplo, sarampo (alta) x poliomielite (baixa).

*⿻一未丷 Virulência - é a capacidade de o agente produzir casos graves ou fatais, deficiência ou incapacidade permanente. Avalia-se através da taxa de letalidade. Associa-se às propriedades bioquímicas do agente relacionadas com a produção de toxinas e a sua capacidade de multiplicação. Por exemplo, raiva (alta) x sarampo (baixa).

* Poder invasor - capacidade de o agente propagar-se depois de sua penetração no organismo, através dos distintos órgãos, tecidos e sistemas.

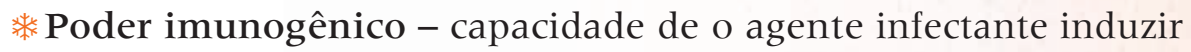
imunidade no hospedeiro. Por exemplo, rubéola, sarampo, caxumba (alto) x tétano (baixo).

* Dose infectante - é a quantidade de agente etiológico necessária para iniciar uma infecção. Varia com a virulência do agente e com a resistência do acometido.

\section{Mecanismo etiológico e duração das doenças}

De acordo com a etiologia, isto é, de acordo com os agentes ou fatores que causam uma doença, as doenças são classificadas em duas categorias:

*⿻ença infecciosa - doença clinicamente manifesta, do homem ou dos animais, resultante de uma infecção. Por exemplo, gripe, tuberculose, catapora etc.

* Doença não infecciosa - doença que não resulta de uma infecção. Por exemplo, envenenamento por picada de cobra, diabetes, hipertensão, obesidade, entre outras.

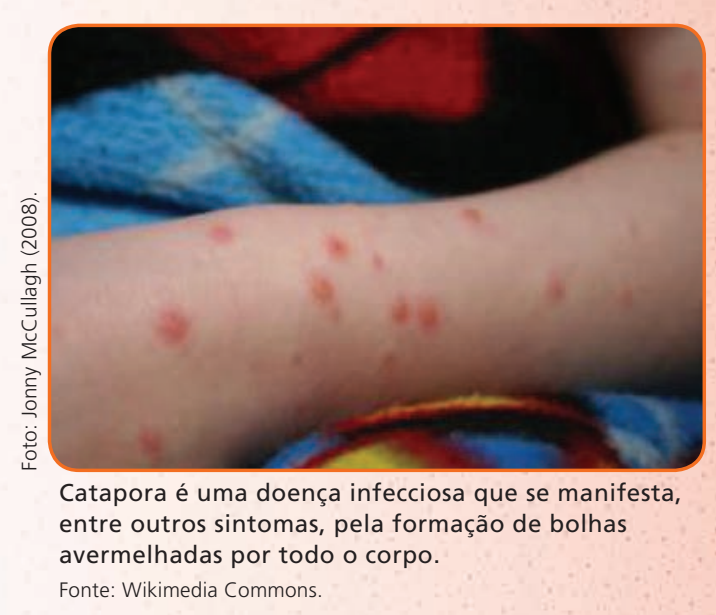


Sob o aspecto da duração, as doenças podem ser:

* Crônicas - que se desenrolam a longo prazo.

*agudas - de curta duração.

Veja alguns exemplos correlacionando essas categorias no Quadro 1.

Quadro 1 - Esquematização de doenças infecciosas e não infecciosas agudas e crônicas

\begin{tabular}{|l|l|l|}
\hline \multirow{2}{*}{ Etiologia } & Duração & Crônicas \\
\cline { 2 - 3 } & Agudas & $\begin{array}{l}\text { tuberculose, hanseníase, doença de } \\
\text { Chagas, leishmaniose }\end{array}$ \\
\hline Infecciosas & tétano, raiva, difteria, sarampo, gripe & diabetes, doença coronariana \\
\hline Não infecciosas & acidentes por animais peçonhentos & . \\
\hline
\end{tabular}

Fonte: Almeida Filho; Rouquayrol (2006).

\section{Classificação e forma de manifestação da doença infecciosa}

A doença infecciosa pode assumir várias formas:

*anifesta - apresenta todas as características clínicas que lhe são típicas. Por exemplo, a pessoa acometida com o vírus que causa catapora apresenta bolhas em todo o corpo, como apresentamos na imagem anterior.

㐘 Inaparente - não apresenta sinais e sintomas clínicos (forma subclínica ou assintomática). Esse tipo de infecção tem grande interesse em epidemiologia, pelo fato de que as pessoas (portadoras) podem transmitir o agente aos suscetíveis com a mesma intensidade encontrada na doença clinicamente manifesta, porém de forma encoberta. Por exemplo, poliomielite, meningites, HIV, hepatites B e C.

畨Latente - período de equilíbrio, não existem sinais clínicos, e o doente ainda não constitui fonte de contágio. Por exemplo, algumas fases da tuberculose.

Abortiva ou frustra - é aquela que desaparece rapidamente após poucos sinais ou sintomas. Por exemplo, na poliomielite abortiva, forma moderada que acontece, principalmente, em crianças jovens, em que o cérebro e a espinha dorsal não são afetados; os sintomas aparecem como uma sensação geral de indisposição e desconforto (como numa gripe).

畨Fulminante - ocorre de forma excepcionalmente grave, com coeficiente de letalidade elevado. Por exemplo, septicemias. 


\section{Períodos ou fases das doenças transmissíveis/ infecciosas}

Antes de se manifestarem por meio de sinais e sintomas, as doenças transmissíveis apresentam fases ou períodos que permitem tomar as medidas necessárias para evitar sua propagação. Esses períodos são de:

* Incubação - intervalo de tempo que decorre entre a exposição a um agente infeccioso e o aparecimento dos sinais e sintomas. Por exemplo, horas, para o cólera; meses ou anos, para hanseníase e Aids.

* Transmissibilidade - período durante o qual o agente infeccioso pode ser transferido direta ou indiretamente de uma pessoa infectada para outra.

Como vimos anteriormente, todas as doenças transmissíveis têm, como fases, períodos de incubação e de transmissão; agora, apresentamos a classificação de todas as fases das doenças transmissíveis.

* Período de incubação - é o intervalo de tempo entre a penetração do agente no organismo e o aparecimento dos primeiros sinais e/ ou sintomas clínicos da doença. Por exemplo, horas, para o cólera; meses ou anos, para hanseníase e Aids.

Fase prodrômica - é o período transitório, com sinais e/ou sintomas inespecíficos, como febre, mal-estar etc.

* Fase sintomática (fase clínica) - é o período das manifestações específicas da doença, como exantema, paralisia etc. É na transição entre a fase prodrômica e a fase sintomática que ocorre o período de transmissão da doença. Em outras palavras, mesmo que ainda não tenham aparecido sinais e sintomas, já pode estar ocorrendo a transmissão do agente etiológico para outra pessoa suscetível.

* Fase de defervescência - é aquela em que a intensidade da doença diminui gradualmente e, de forma progressiva, desaparecem os sinais e sintomas clínicos.

* Fase de convalescença - é o período de restauração gradual da função e da morfologia dos órgãos e sistemas, assim como do restabelecimento da capacidade de reação e adaptação do organismo aos fatores do meio.

\section{Esquemas e tipos de transmissão}

Até agora informamos sobre o que é a doença transmissível, como ocorre, suas formas e fases, mas como são definidos os ciclos de transmissão das doenças, quais são os tipos de transmissão? 
As doenças transmissíveis podem ocorrer através de três esquemas básicos:

Esquema 1 - Dois fatores vivos envolvidos: hospedeiro suscetível e agente infeccioso

Pode se expressar de três formas:

a) indivíduo infectado e indivíduo suscetível pertencem à mesma espécie (é o caso da sífilis, doença transmitida sexualmente);

b) duas espécies hospedeiras envolvidas (é o caso da raiva, que acomete tanto um cachorro quanto um humano);

c) meio ambiente contaminado e hospedeiro suscetível (micoses, possível de se pegar numa praia, por exemplo, e tétano, por meio de corte com objeto contaminado, em geral enferrujado).

Esquema 2 - Três fatores vivos envolvidos: hospedeiro, agente infeccioso e hospedeiro intermediário (vetor)

Um exemplo é a esquistossomose. Essa doença é causada pelo helminto Schistosoma mansoni, que precisa desenvolver uma parte do seu ciclo de vida em um caramujo para, depois, infectar seu hospedeiro definitivo, que é o ser humano.

Esquema 3 - Quatro fatores vivos envolvidos: hospedeiro, agente infeccioso, hospedeiro intermediário (vetor) e hospedeiro acidental

Exemplos: febre amarela silvestre, animal (macacos), vetor (mosquito/gênero haemagogus), animal (macacos); o ciclo terminaria, novamente no macaco, mas o homem, ocasionalmente, ao penetrar na floresta, poderá infectar-se e passar a constituir o quarto fator desse esquema.

\section{Tipos de transmissão}

Existem várias formas de transmissão de doenças encontradas na natureza, e essas variam dependendo da infecção. As transmissões de doenças podem ser classificadas em vertical, horizontal, ou ambas, sendo a horizontal subdividida em vias (contato direto ou indireto), conforme detalhes a seguir.

1. Transmissão vertical - Também conhecida como materno-infantil, é a transmissão de uma geração para seus descendentes, podendo ser passada ainda no período de gestação, no nascimento e/ou mesmo nos primeiros anos de vida por meio do leite materno. 
Doenças como a hepatite B e C, sífilis e Aids podem ocorrer por esse tipo de transmissão.

2. Transmissão horizontal - É a transferência do patógeno de um indivíduo infectado para outro indivíduo sadio, independentemente do relacionamento de parentesco entre eles. Pode ocorrer por contato direto ou indireto.

a) Transmissão direta - É a transferência direta do agente infeccioso de um hospedeiro para outro, levando a cabo a infecção humana ou animal. Isso pode ocorrer através do beijo, de relações sexuais, lambedura ou mordedura no caso da raiva. Pode ser:

- Imediata - contato íntimo entre a fonte e o suscetível, sem interferência do meio; por exemplo, doenças sexualmente transmissíveis.

- Mediata - realiza-se graças à capacidade de o agente permanecer viável no meio durante certo período de tempo; por exemplo, doenças de transmissão respiratória.

b) Transmissão indireta - Possui como característica a capacidade de o agente permanecer no ambiente até alcançar novo hospedeiro, através de uma série de veículos, que podem ser:

- Inanimados - água, alimentos. É o caso da cólera, por exemplo.

- Animados - vetores, que são veículos vivos que transportam um agente infeccioso até um indivíduo suscetível, sua comida ou seu ambiente imediato. Um exemplo é a dengue.

\section{Hospedeiro}

É uma pessoa ou animal vivo, inclusive aves e artrópodes, que, em circunstâncias naturais, permite a subsistência ou o alojamento de um agente infeccioso. Por exemplo, o ser humano é hospedeiro para o vírus da rubéola; equinos, bovinos e caninos são hospedeiros para um gênero de protozoários que causam a doença babesiose.

Existem características que podem favorecer a condição de hospedeiro, tais como: idade, sexo, grupo étnico, estado geral de saúde, fatores comportamentais, situação social, ocupação etc.

$\mathrm{Na}$ epidemiologia das doenças transmissíveis, podemos adotar os seguintes termos para hospedeiro:

* Suscetível - É o hospedeiro que possui condições próprias de receptividade, permitindo a entrada e a colonização do agente em seu organismo, isto é, o suscetível é aquele que não possui resistência a determinado agente patogênico e que, por essa razão, pode contrair a doença, se colocado em contato com o mesmo. 
Os imunobiológicos atuam no sistema imune humoral. A discussão sobre como isso funciona será apresentada com maior profundidade no Capítulo 9, "Noções de imunologia: sistema imunológico, imunidade e imunização".
* Resistente - É o hospedeiro que possui defesas específicas que impedem a invasão do agente.

Discorrer sobre hospedeiro suscetível e resistente nos remete a mais alguns conceitos, os quais serão importantes para o entendimento desses termos.

O primeiro deles é a resistência - trata-se do conjunto de mecanismos corporais que servem de defesa contra a invasão ou multiplicação de agentes infecciosos, ou contra os efeitos nocivos de seus produtos tóxicos. Um tipo de resistência é a inespecífica ou natural - são barreiras físicas contra a invasão de microrganismos, como a desempenhada pela nossa pele.

Outro tipo de resistência, específica, resulta de mecanismos imunitários, ou seja, é a nossa imunidade. Imunidade é o estado de resistência associado à presença de anticorpos que possuem ação específica sobre o microrganismo responsável por uma doença infecciosa ou sobre suas toxinas (OPAS/OMS, 1992). A imunidade pode ser celular, quando é mediada por células do sistema imunológico, ou humoral, quando é mediada por anticorpos. Pode, também, ser:

* Passiva - Quando obtida naturalmente através da transmissão materna (via transplacentária) ou artificialmente, por inoculação de anticorpos protetores específicos (soro, imunoglobulina humana etc.).

* Ativa - Quando adquirida como consequência de uma infecção, ou artificialmente, por meio de vacinas.

\section{Portador}

Quando um hospedeiro é infectado por um agente patogênico e é passível de abrigá-lo e transmiti-lo a outros, dizemos que esse hospedeiro é um portador. O portador pode ser classificado em dois tipos:

* ativo - quando elimina o agente infeccioso e não apresenta sintomas no momento em que está sendo examinado, mas já os apresentou ou apresentará;

* passivo - quando elimina o agente infeccioso e não apresenta nem apresentará os sintomas.

O portador passivo, sob o ponto de vista epidemiológico, é o mais importante, pois dissemina o microrganismo patogênico sem apresentar a doença. Imagine quantas pessoas podem ser contaminadas sem saber, e esse fato pode desencadear uma epidemia! 
Em muitos casos, a vacinação é de suma importância para a eliminação do agente infeccioso no portador passivo; temos como exemplo a difteria e a meningite.

\section{Ambiente nas doenças transmissíveis}

Completando a nossa discussão sobre hospedeiro e portador, devemos conhecer o que é reservatório e, antes disso, qual a influência do ambiente para sua instalação.

O ambiente inclui todos os fatores que não são específicos do agente infeccioso ou do hospedeiro. Os fatores específicos do ambiente interagem com os fatores do agente e do hospedeiro na promoção ou na manutenção da doença. São fatores do ambiente: físicos (clima, relevo etc.), biológicos (flora, fauna etc.) e socioeconômicos.

De forma geral, o ambiente é visto como reservatório de bioagentes. Portanto, reservatório pode ser um humano ou animal, planta, solo, em que um agente infeccioso vive normalmente e no qual se reproduz de modo a poder ser transmitido a um hospedeiro suscetível.

\section{Veículos e vetores}

O que são vetores, o que são veículos? Quais são as suas responsabilidades na transmissão das doenças?

Vetores são seres vivos que veiculam o agente infeccioso desde o reservatório até o hospedeiro. O agente pode ou não se desenvolver, propagar ou multiplicar dentro do vetor. Os vetores podem ser:

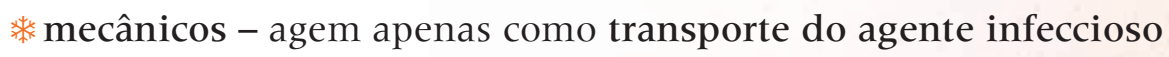
por meio de um inseto, seja por contaminação de suas patas, trompas ou pela passagem através de seu trato intestinal, sem multiplicação ou desenvolvimento do microrganismo;

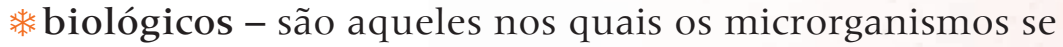
desenvolvem, pelo menos em uma fase do seu ciclo vital, antes de serem disseminados no ambiente ou inoculados em novo hospedeiro. A transmissão pode ocorrer de diversas formas: por meio da saliva, durante a picada (como na malária, dengue e febre amarela); por regurgitação (como na peste); ou ao depositar sobre a pele os agentes infecciosos com a defecação do artrópode vetor (como na doença de Chagas e no tifo exantemático), que podem entrar pela ferida da picada ou ao se coçar.

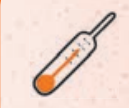

Repare que esta classificação está centrada no uso que o agente patogênico faz do vetor, se ele o utiliza apenas como transporte ou se usa sua estrutura biológica para desenvolvimento e reprodução, além do transporte ao meio ou ao hospedeiro. 

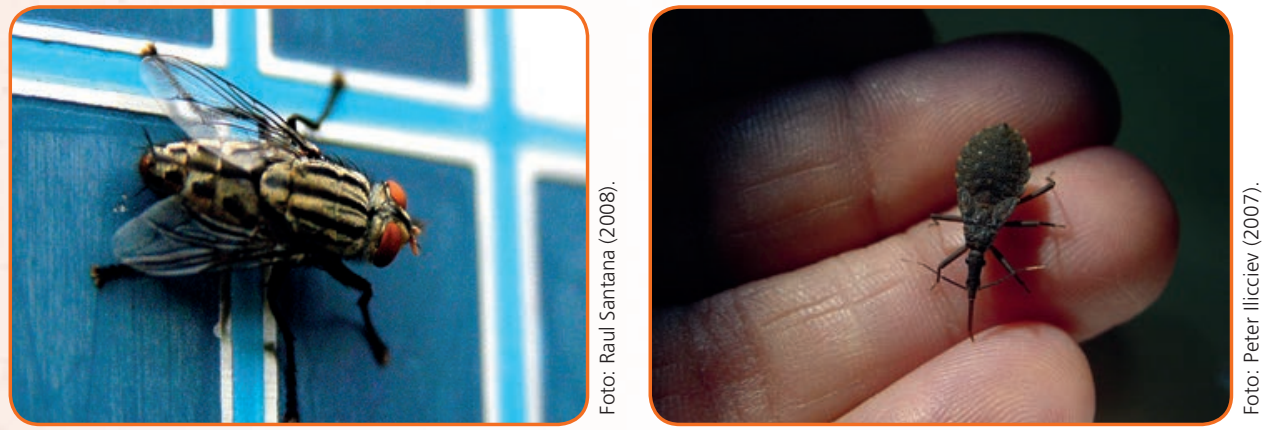

A mosca é um exemplo de um possível vetor mecânico: ao pousar em algo contaminado, pode transportar o agente contaminante para outro ambiente ou hospedeiro. Já o barbeiro, artrópode triatomíneo, atua como vetor biológico para a doença de Chagas, uma vez que seu agente causador (o protozoário Trypanosoma cruzi) desenvolve parte do seu ciclo de vida dentro desse inseto.

Fonte: Fiocruz Imagens.

Veículos são objetos ou materiais contaminados que servem de meio mecânico, auxiliando um agente infeccioso a ser transportado e introduzido em um hospedeiro suscetível.

São classificados como veículos a água, o leite e outros alimentos; objetos contaminados (roupas de cama, utensílios de cozinha, instrumentos cirúrgicos, alicates de unha); partículas do solo, poeira em suspensão; e produtos biológicos (por exemplo, sangue).

\section{Referências}

ALMEIDA FILHO, N.; ROUQUAYROL, M. Z. Introdução à epidemiologia. 4. ed. rev. e ampl. Rio de Janeiro: Guanabara Koogan, 2006.

BRASIL. Ministério da Saúde. Secretaria de Atenção à Saúde. Departamento de Atenção Básica. Vigilância em saúde: zoonoses. Brasília, DF, 2009.

BRASIL. Ministério da Saúde. Secretaria de Vigilância em Saúde. Guia de vigilância epidemiológica. 7. ed. Brasília, DF, 2009.

MEDRONHO, R. A. et al. Epidemiologia. 2. ed. São Paulo: Atheneu, 2009.

ORGANIZAÇÃO PAN-AMERICANA DA SAÚDE. Módulos de princípios de epidemiologia para o controle de enfermidades: módulo 2: saúde e doença na população. Brasília, DF, 2010. 